\title{
La necesaria revisión de la eficacia de los pactos parasociales omnilaterales o de todos los socios
}

\author{
Aránzazu Pérez Moriones \\ Profesora Titular de Derecho Mercantil \\ Universidad del País Vasco (UPV-EHU)
}

\begin{abstract}
Sumario: 1. Planteamiento-2. La eficacia de los pactos parasociales. 2.1. Introducción. 2.2. Antecedentes. 2.3. La eficacia meramente «inter partes» de los pactos parasociales. - 3. La necesaria revisión de la eficacia de los pactos parasociales. 3.1. La situación en ordenamientos jurídicos de nuestro entorno. 3.2. El estado de la cuestión en el ordenamiento español. 3.2.1. Antecedentes: la orientación jurisprudencial favorable al reconocimiento de eficacia societaria a los pactos parasociales de todos los socios o pactos parasociales omnilaterales. 3.2.2. El estado de la cuestión tras las sentencias dictadas por el Tribunal Supremo en relación con el grupo «Kurt Konrad y Cía, S.A.». 3.2.3. Una última vuelta de tuerca acerca de la eficacia societaria de los pactos parasociales de todos los socios o pactos omnilaterales: la sentencia de la Audiencia Provincial de Madrid de 16 de noviembre de 2012. 3.3. La eficacia societaria de los pactos parasociales de todos los socios o pactos parasociales omnilaterales. 3.4. Consecuencias de la eficacia societaria de los pactos parasociales de todos los socios o pactos parasociales omnilaterales.
\end{abstract}

\section{PLANTEAMIENTO}

Últimamente se han publicado varios trabajos doctrinales en los que se han estudiado diversas cuestiones relacionadas con los pactos parasociales. Las razones que justifican este interés se encuentran, probablemente, en la cada vez mayor utilización práctica de este instrumento, así como en varias sentencias dictadas por el Tribunal Supremo que han producido cierta controversia. Es necesario, desde luego, reconocer que en tan solo unos años se han producido importantes novedades legislativas y jurisprudenciales sobre la materia, las cuales obligan al replanteamiento de algunas cuestiones. En este sentido, las dudas que hace unos años se suscitaban en relación con la licitud y validez de los pactos parasociales han quedado definitivamente superadas $^{1}$. Basta tener presente el reflejo legislativo, directo o indirecto, que

${ }^{1}$ La jurisprudencia los ha considerado negocios jurídicos válidos en las SSTS de 27 de septiembre de 1961; de 10 de noviembre de 1962; de 28 de septiembre de 1965; de 24 de septiembre de 1987, Ref. Aranzadi, núm. 6194; de 26 de febrero de 1991, Ref. Aranzadi, núm. 1600; de 10 de febrero de 1992, Ref. Aranzadi núm. 1204; de 18 de marzo de 2002, Ref. Aranzadi n ${ }^{\circ}$ 2850); de 19 de diciembre de 2007, Ref. Aranzadi núm. 9043, con comentario de Pérez Millán, D., «Sobre los pactos parasociales. Comentario a la STS $1^{\text {a }}$ 
han recibido en la Ley 26/2003, por la que se modifican la Ley 24/1988, de 28 de julio, del Mercado de Valores, y el texto refundido de la Ley de Sociedades Anónimas, aprobado por el Real Decreto Legislativo 1564/1989, de 22 de diciembre, con el fin de reforzar la transparencia de las sociedades anónimas cotizadas²; y, posteriormente, en el Real Decreto 17/2007, de 9 de febrero, por el que se regula la publicidad de los protocolos familiares ${ }^{3}$, o en la Ley 2/2007, de 15 de marzo, de Sociedades Profesionales ${ }^{4}$. Sin embargo,

de 19 de diciembre de 2007», $R d S$, núm. 31, 2008, p. 383 y ss.; o de 10 de diciembre de 2008.

${ }^{2}$ Ley 26/2003, por la que se modifican la Ley 24/1988, de 28 de julio, del Mercado de Valores, y el texto refundido de la Ley de Sociedades Anónimas, aprobado por el Real Decreto Legislativo 1564/1989, de 22 de diciembre, con el fin de reforzar la transparencia de las sociedades anónimas cotizadas, Boletín Oficial del Estado, 18 de julio de 2003, núm. 171, p. 28046 y ss. Al respecto, pueden consultarse FernÁndez Pérez, N., «El significado de la Ley de Transparencia en la modernización del derecho societario español», $R d S$, núm. 22, 2004, p. 87 y ss.; García de Enterría Lorenzo-Velázquez, J., «Cuestiones sobre el régimen de transparencia de los pactos parasociales en las sociedades cotizadas», Revista de Derecho del Mercado de Valores, núm. 7, 2010, p. 137 y ss.; Giner García, D., «Aproximación a la regulación del sistema de publicidad de los pactos parasociales en la Ley 26/2003», Diario La Ley, 2003, p. 1891 y ss.; IllesCAS OrTIZ, R., «La transparencia de las Sociedades Anónimas cotizadas y los pactos parasociales», DN, núm. 165, 2004, p. 5 y ss.; LeÓN SANZ, F. J., «La publicación de los pactos parasociales por las sociedades cotizadas», en Rodríguez Artigas, F. (coord.), Derecho de sociedades anónimas cotizadas (estructura de gobierno y mercados), Volumen 2, Aranzadi, Cizur Menor (Navarra), 2006, p. 1167 y ss.; Mambrilla Rivera, V. M., «Los pactos parasociales y la transparencia de las sociedades anónimas cotizadas: análisis de su tratamiento en la Ley 26/2003», RdS, núm. 22, 2004, p. 205 y ss.; Recalde Castells, A. y De Dios Martínez, L. M., «Los pactos parasociales en la Ley de Transparencia: una cuestión polémica», Diario La Ley, 2004, p. 1585 y ss.; SÁNCHEZ ANDRÉs, A., «La disposición transitoria tercera 2.c de la llamada Ley de Transparencia como interpretación auténtica de normas anteriores», en SÁNCHEZ Andrés, A., Estudios de Derecho de sociedades y Derecho concursal. Libro homenaje al Profesor Rafael García Villaverde, Tomo II, Marcial Pons, Madrid, 2007, p. 1155 y ss.; o Sánchez-Calero Guilarte, J., «Los pactos parasociales anteriores a la entrada en vigor de la Ley de Transparencia», Documentos de Trabajo del Departamento de Derecho Mercantil, Universidad Complutense, Madrid, 2007.

3 Real Decreto $17 / 2007$, de 9 de febrero, por el que se regula la publicidad de los protocolos familiares, Boletín Oficial del Estado, 16 de marzo de 2007, núm. 65, p. 11254 y ss. Por todos, ver Fernández del Pozo, L., «El “enforcement” societario y registral de los pactos parasociales. La oponibilidad de lo pactado en protocolo familiar publicado», $R d S$, núm. 29, 2007, p. 139 y ss.; Rodríguez DíAz, I., «El protocolo familiar y su publicidad: de las iniciativas comunitaria y española al Real Decreto 171/2007, de 9 de febrero, por el que se regula la publicidad de los protocolos familiares», $R D M, 2007$, p. 1123 y ss.; o Vicent Chuliá, F., «La publicidad del Protocolo Familiar (RD 171/2007, de 9 de febrero)», $R J C, 2008$, p. 51 y ss.

${ }^{4}$ Ley $2 / 2007$, de 15 de marzo, de Sociedades Profesionales, Boletín Oficial del Estado, 16 de marzo de 2007, núm. 65, p. 11246 y ss. Sobre la mencionada Ley y su vinculación específicamente con el tema de los pactos parasociales, Feliú ReY, J., Los pactos parasociales en las sociedades de capital no cotizadas, Marcial Pons, Madrid, 2012, p. 83 y ss. 
uno de los principales problemas prácticos que presentan los pactos parasociales -su limitada eficacia- no ha sido resuelto, al menos satisfactoriamente. De hecho, como quedará confirmado en páginas posteriores, la eficacia y, en estrecha conexión con esta última, los problemas que se producen como consecuencia del incumplimiento de los pactos parasociales constituyen una materia de preocupación para los operadores jurídicos. En efecto, si los pactos parasociales presentan eficacia «inter partes» únicamente vinculan a los socios que han participado en los mismos, pero no a los socios no intervinientes en ellos, a la sociedad o a terceros. De ahí los altos riesgos de incumplimiento que conllevan. A la luz de algunas experiencias planteadas ante nuestros tribunales, resulta necesario un replanteamiento de la eficacia de los pactos parasociales, siquiera respecto de aquellos pactos parasociales en los que han participado todos los socios, es decir, los denominados pactos parasociales omnilaterales. Con todo, en fechas recientes, se ha entregado al Ministro de Justicia la Propuesta de Código Mercantil, resultado de un largo trabajo realizado por la Sección de Derecho Mercantil de la Comisión General de Codificación, iniciado en el año 2006. Pues bien, una de las novedades que se contiene en dicha Propuesta es un régimen básico de los pactos parasociales ${ }^{5}$, en el que se incluye una previsión acerca de la eficacia de los mismos; regulación a la que se suma la de los pactos parasociales sujetos a publicidad, materia que constituye el capítulo IV del Título VIII «De las sociedades anónimas cotizadas»».

\section{LA EFICACIA DE LOS PACTOS PARASOCIALES}

\subsection{Introducción}

Con carácter previo al análisis de la eficacia de los pactos parasociales, resulta necesario realizar una matización de carácter terminológico. Como comprobaremos en páginas siguientes, en nuestro ordenamiento se ha utilizado la expresión «pactos reservados» -y no «pactos parasociales»-, incluso con posterioridad al momento en que esta última es acuñada. En efecto, la utilización de la expresión «pactos reservados» durante el siglo XIX y mitad del siglo XX resulta lógica, al no existir la segunda. Pero tampoco una vez creada, la expresión «pactos parasociales» es usada por el legislador español. Pues bien, esta opción parece responder a la circunstancia de que esta última denominación no presentaba especial difusión a mediados del siglo XX y su sustitución con ocasión de la redacción de la LSA 1951 podía entorpecer que se apreciase el alcance de la novedad introducida en el art. 6 del mencionado texto legal, es decir, el reconocimiento de la licitud de tales pactos ${ }^{6}$. Recuér-

${ }^{5}$ Utilizamos la expresión contenida en el punto III.14 de la Exposición de Motivos de la Propuesta.

${ }^{6}$ Tal y como apunta Noval Pato, J., Los pactos omnilaterales: su oponibilidad a la sociedad. Diferencias y similitudes con los estatutos y los pactos parasociales, Civitas 
dese que el término «pacto parasocial» tiene su origen en la expresión «contratos parasociales», acuñada por OpPO en 1942 en su monografía Contratti parasociali, la cual comprende aquellos contratos en los que intervienen todos o algunos de los socios de una sociedad, formalizados bien en el momento de su constitución, bien a lo largo de la vida de la misma, y mediante los cuales aquéllos completan o modifican el régimen legal o estatutario previsto para la sociedad, comprometiéndose a actuar de un modo predeterminado ${ }^{7}$. La doctrina italiana rápidamente admitió sin reservas la trascendencia y la difusión de estos contratos en la praxis societaria ${ }^{8}$, llegándose a afirmar que ninguna sociedad podría funcionar con regularidad sin la existencia de tales acuerdos y transacciones negociales, establecidos por los socios fuera de los esquemas societarios y dirigidos a la realización de la actividad común ${ }^{9}$. Sin embargo, no es hasta años más tarde cuando esta expresión es utilizada en algunos textos del Derecho de sociedades italiano, por ejemplo, en el artículo 2.5 de la Ley de 5 de agosto de 1981, núm. 416, sobre empresas editoriales ${ }^{10}$, o en el artículo 37 de la Ley de 6 de agosto de 1990, núm. 223, que completa el artículo 2359 del Código civil ${ }^{11}$. Por su parte, la jurisprudencia italiana ha reconocido progresivamente la existencia de los contratos parasociales como categoría jurídica autónoma ${ }^{12}$.

La denominación «pactos parasociales» es introducida en nuestro país por la doctrina mercantilista más reconocida ${ }^{13}$, aunque no es utilizada por el legislador hasta el año $2003^{14}$, cuando al título X de la Ley 24/1998, de 28 de julio, del Mercado de Valores se añade un capítulo II, bajo la rúbrica «De los pactos parasociales sujetos a publicidad», a su vez formado por un solo

\section{Thomson Reuters, 2012, pp. 135 y 136.}

7 Ver Oppo, G., Contratti parasociali, Casa Editrice Dott. Francesco Vallardi, Milán, 1942, p. 3.

${ }^{8} \mathrm{Al}$ respecto, véase Pérez Moriones, A., Los sindicatos de voto para la junta general de accionistas de sociedad anónima, Tirant lo Blanch, Valencia, 1996, p. 259, nota núm. 5 , con ulteriores referencias bibliográficas.

9 Así, SAntoni, G., Patti parasociali, Pubblicazioni Della Facoltà giuridica dell 'Università di Napoli, Casa Editrice Dott. Eugenio Jovene, Napoli, 1985, p. 2.

10 «En el caso de acuerdos parasociales o de sindicatos de voto entre sociedades titulares de cabeceras de periódicos, que permiten el control, el que haya estipulado el acuerdo o participado en la constitución del sindicato tiene la obligación de efectuar la comunicación a la que se refiere el primer párrafo»».

${ }^{11}$ En dicho artículo se prevé que existe una relación de control cuando este último se realiza, además, «conjuntamente con otros sujetos...mediante acuerdos parasociales».

12 Nos remitimos a Pérez Moriones, A., Los sindicatos de voto para la junta general de accionistas de sociedad anónima, ob. cit., p. 260.

${ }_{13}$ Así, Garrigues, J., «Sindicatos de accionistas», $A A M N$, Tomo IX, 1957, p. 91 y ss.

14 Dicha reforma se lleva a cabo mediante la Ley 26/2003, por la que se modifican la Ley 24/1988, de 28 de julio, del Mercado de Valores, y el texto refundido de la Ley de Sociedades Anónimas, aprobado por el Real Decreto Legislativo 1564/1989, de 22 de diciembre, con el fin de reforzar la transparencia de las sociedades anónimas cotizadas, ya mencionada anteriormente. 
artículo, en donde se regula la publicidad de los pactos parasociales y de otros pactos que afecten a una sociedad cotizada. Este artículo es derogado como consecuencia de la entrada en vigor de la LSC, cuyo capítulo VIII del título XIV, «Sociedades anónimas cotizadas», contiene la regulación aplicable a los «Pactos parasociales sujetos a publicidad»-arts. 530 a 535 LSC-. Como resultado, es a comienzos de este siglo cuando se acoge la expresión «pactos parasociales» de forma definitiva en la legislación societaria española, aunque convive con el término tradicionalmente utilizado de «pactos reservados», que se mantiene en el artículo $29 \mathrm{LSC}^{15}$.

\subsection{Antecedentes}

Ya el Código de comercio de 1829 dedica dos de sus preceptos a los pactos reservados. Así, en su artículo 287 se declara que «(L)os socios no pueden hacer pactos algunos reservados, sino que todos han de constar en la escritura social». Esta previsión queda completada en el artículo siguiente, en el que se señala que «(L)os socios no pueden oponer contra el contenido de la escritura de sociedad documento alguno privado, ni prueba testimonial». La razón justificativa de esta doble prohibición debe encontrarse en la influencia del Código de comercio francés de 1807, a su vez influido por la Ordenanza del Comercio de 1673. Este último cuerpo legal exigía a las sociedades el cumplimiento de ciertos requisitos de forma y publicidad, los cuales tenían como finalidad última dar a conocer las relaciones ocultas que existían en el marco de sociedades comanditarias con base en las cuales los socios comanditarios permanecían ocultos, evitando responder frente a terceros o convirtiéndose en acreedores frente a la sociedad ${ }^{16}$. A su vez, el incumplimiento de aquellos requisitos conllevaba la nulidad de la sociedad.

El Código de comercio de 1885 mantiene en su artículo 119.3 la prohibición establecida en el Código de comercio de 1829, al prever que «(L)os socios no podrán hacer pactos reservados, sino que todos deberán constar en la escritura social». Sin embargo, la claridad de la declaración contenida en el mencionado precepto es más aparente que real. En efecto, la misma es interpretada no en el sentido de que todo pacto celebrado entre los socios que no consta en la escritura social y que, por lo tanto, ha de ser calificado como reservado, está prohibido. Antes bien, el Tribunal Supremo matiza esta declaración en una serie de sentencias dictadas a finales del siglo XIX y comienzos del siglo XX. Así, en sentencia de 16 de julio de 1891, el Alto Tribunal se pronuncia sobre un pacto mediante el cual un socio colectivo asegura a un socio comanditario las pérdidas que pueda experimentar en el capital apor-

15 Por lo demás, la Propuesta de Código Mercantil se sirve de la denominación «pactos parasociales», tanto en el régimen básico de los pactos parasociales como en el específico de los pactos parasociales en sociedades cotizadas.

16 Tal y como señala Feliú ReY, J., Los pactos parasociales en las sociedades de capital no cotizadas, ob. cit., p. 32. 
tado a la sociedad comanditaria y le garantiza una ganancia del veinticinco por ciento de interés en dicho capital. Aquel declara la validez del pacto por entender que «...es éste un convenio notoria y absolutamente desligado de la vida y existencia de la Sociedad...no pudiendo confundirse el alcance y los efectos de una y otra escritura, por ser referentes a derechos y obligaciones que tienen una esfera de acción y realización distintas...y que por ella en nada se alteran las condiciones de la Sociedad comanditaria». El Tribunal Supremo concluye que «...no hay disposición legal alguna que prohíba a los socios, sólo por serlo de una Sociedad determinada, pactar luego entre sí en los términos en que los hicieron las partes»; declaración que es reiterada por el Tribunal Supremo en su sentencia de 16 de febrero de $1901^{17}$. Siguiendo la misma orientación, el Alto Tribunal sostiene en sentencia de fecha 24 de febrero de 1902 que «...de los artículos 1255, 1230 y 1278 del Código civil, ni de la doctrina de que si bien los contratos mercantiles se rigen por el Derecho común en cuanto a las causas que los rescinden o invalidan, esta regla general está limitada por las modificaciones y las restricciones que establece el Derecho mercantil, se deriva la conclusión de que los socios no puedan pactar entre sí en cualquier forma lo que a sus intereses convenga, en cuanto no perjudique o se relacione con derechos de tercero, siempre que los pactos reúnan las condiciones esenciales de validez». Por último, en un supuesto similar al que constituye objeto de la primera sentencia, el Alto Tribunal, en sentencia de 10 de junio de 1904, considera que «...estipulándose por un socio colectivo y otro comanditario a favor de éste la indemnización, con hipoteca de bienes del primero, de las pérdidas resultantes de la liquidación que se practique a la disolución de la sociedad, y el abono de las utilidades del capital del mismo, según cada balance, es incuestionable que tales pactos son independientes y opuestos a cuanto pueda relacionarse con la existencia de la sociedad, siendo, por tanto, sus efectos, en orden a los contratantes y respectivos herederos, de carácter meramente civil, y debiendo regularse las obligaciones y responsabilidad que de aquellos pactos se derivan por la legislación común». En definitiva, el Tribunal Supremo declara la licitud de los pactos celebrados entre socios no incluidos en los estatutos sociales, pero, al mismo tiempo, subraya de manera indubitada la diferente esfera de actuación de unos y otros. Como resultado, tras las interpretaciones del artículo 119.3 Ccom sostenidas por el Tribunal Supremo, se entiende que la declaración contenida en este precepto no implica una prohibición absoluta de la celebración de pactos entre socios no incluidos en la escritura social, sino que simplemente impide que tales pactos -celebrados entre socios pero no incorporados a la escritura social- surtan efectos sociales, es decir, entre socios y sociedad.

${ }^{17}$ En la que se señala que «...no hay disposición legal alguna que prohíba a los socios, sólo por serlo de una sociedad determinada, pactar luego entre sí con relación a derechos y obligaciones que tienen una esfera de acción y realización distinta de aquélla». 
Con posterioridad, la LSA 1951 se pronuncia con mayor rotundidad en relación con los pactos reservados. En efecto, a tenor de su artículo 6.3, «(S)on nulos los pactos sociales que se mantengan reservados». Recuérdese que el Ccom se limita a prohibir que los socios puedan celebrar pactos reservados, pero no establece la sanción correspondiente. En este caso, la LSA declara la nulidad no de los pactos reservados - siguiendo la expresión del Ccom 1885- sino de «los pactos sociales que se mantengan reservados». Con todo, la doctrina se muestra dividida respecto del alcance de este precepto. Así, mientras que cierto sector sostiene que aquella declaración impide que los pactos entre socios no incorporados a la escritura social surtan efecto alguno ${ }^{18}$, ni siquiera entre los participantes en los mismos, otro sector matiza la sanción de nulidad, defendiendo su eficacia «inter partes», siempre que tales pactos no afecten a elementos esenciales de la escritura ${ }^{19}$. Incluso, un último sector de la doctrina postula que la nulidad no se aplica a aquellos pactos que tienen por objeto relaciones de los socios entre sí en su cualidad de tales, pero que no deben considerarse en sentido estricto como pactos sociales ${ }^{20}$.

Por último, los artículos 7.1 LSA 1989 y 11.2 LSRL 1995 se alejan de la declaración contenida en la LSA 1951, ya que se limitan a declarar la inoponibilidad frente a la sociedad de los pactos que se mantengan reservados entre los socios. En efecto, atendiendo a ambos preceptos, «Los pactos que se mantengan reservados entre los socios no serán oponibles a la sociedad». Con todo, esta declaración presenta un indudable interés ${ }^{21}$ : por un lado, porque deroga la sanción de nulidad contenida en la LSA 1951 y, por otro lado, porque acoge el criterio doctrinal favorable a la validez y eficacia entre los intervinientes de los pactos de carácter obligacional. En efecto, no podemos olvidar que el art. 6.3 LSA 1951 declaraba la nulidad de los pactos sociales que se mantuvieran reservados, con independencia de las distintas interpretaciones realizadas por los estudiosos de la materia, más proclives unos que otros a otorgar cierta eficacia a dichos pactos. A su vez, la admisibilidad de tales pactos se fundamenta en una interpretación «a sensu contrario» de la declaración legal. En efecto, si los pactos reservados no tienen eficacia frente a la sociedad, ello implica que tienen eficacia entre quienes han participado en ellos ${ }^{22}$. En definitiva, como ha sido afirmado de una forma muy gráfica, «...se pasa de una presunción de nulidad del pacto reservado y del para-

${ }_{18}$ Así, Garrigues, J., en Garrigues, J. y Uría, R., Comentario a la Ley de Sociedades Anónimas, Tomo I, $3^{\mathrm{a}}$ ed., Aguirre, Madrid, 1976, p. 169.

19 Así, Gay de Montellá, R., Tratado de Sociedades Anónimas, Bosch, Barcelona, 1952 , p. 72.

${ }^{20}$ En este sentido, Velasco Alonso, A., La Ley de sociedades anónimas. Anotaciones y concordancias, $5^{\mathrm{a}}$ ed., Editorial de Derecho Financiero, Editoriales de Derecho Reunidas, Madrid, 1982, p. 67 y ss.

${ }_{21}$ Destaca igualmente esta cuestión Fernández de la GÁndara, L., voz «Pacto parasocial», en Enciclopedia Jurídica Básica, Volumen III, Civitas, Madrid, 1995.

${ }_{22}$ Así, Vaquerizo, A., en Rojo, A. y Beltrán, E. (coords.), Comentario de la Ley de Sociedades de Capital, Tomo I, Civitas-Thomson Reuters, Madrid, 2011, p. 397. 
social, salvo que se demuestre lo contrario, a una presunción de licitud y validez, aunque de eficacia limitada, salvo que se demuestre lo contrario ${ }^{23}$.

\subsection{La eficacia meramente «inter partes» de los pactos parasociales}

El artículo 29 LSC, actualmente en vigor, reproduce literalmente el contenido de los artículos 7.1 LSA 1989 y 11.2 LSRL 1995, de modo que carecemos de una definición legal de «pactos reservados». Ahora bien, la lectura de aquel precepto - «Los pactos que se mantengan reservados entre los socios no serán oponibles a la sociedad»- ha conducido a la equiparación por parte de la doctrina mayoritaria entre pacto reservado y pacto no incluido en los estatutos, lo que, a su vez, conlleva que si todo pacto no incluido en los estatutos sociales es un pacto reservado, todo pacto no incluido en los estatutos sociales es inoponible a la sociedad ${ }^{24}$. Este carácter no oponible a la sociedad tiene su razón de ser en la autonomía e independencia que presentan tales pactos frente al contrato social y frente a la propia organización corporativa ${ }^{25}$. Como resultado, los pactos no incluidos en los estatutos o pactos extraestatutarios tienen una eficacia limitada al ámbito interno, es decir, vinculan exclusivamente a aquellos socios que han participado en ellos ${ }^{26}$. Dicho de

${ }^{23}$ Véase Feliú Rey, J., Los pactos parasociales en las sociedades de capital no cotizadas, ob. cit., p. 44.

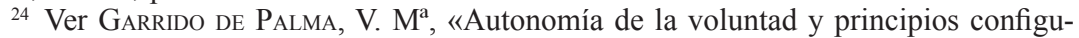
radores. Su problemática en las sociedades anónimas y de responsabilidad limitada», en Estudios en homenaje al profesor Aurelio Menéndez, Tomo II, Civitas, Madrid, 1996, p. 1870; Sanchez Álvarez, M., «Comentario a la Sentencia de 5 de marzo de 2009», CCJC, núm. 81, 2009, pp. 1371 y 1377; y MadrideJos FernándeZ, J. Maa «La inoponibilidad de los pactos parasociales frente a la sociedad. Comentario a la Sentencia del Tribunal Supremo de 6 de marzo de 2009», CDC, núm. 53, 2010, p. 301.

${ }_{25}$ Así, Vaquerizo, A., en Rojo, A. y Beltrán, E. (coords.), Comentario de la Ley de Sociedades de Capital, ob. cit., pág. 400.

${ }^{26}$ Por todos, Sánchez CAlero, F., La Junta General en las sociedades de capital, Thomson Civitas, Madrid, 2007, pp. 299 y 300. Consecuencia también declarada por los tribunales en las ocasiones en que se ha pronunciado al respecto-ver, entre otras, SAP de Córdoba de 14 de julio de 2005, que señala que «el pacto suscrito nunca puede afectar a la sociedad que como persona jurídica independiente, es obvio decirlo, en modo alguno intervino, y lo que es más importante, quedó oculto, sin publicidad alguna»; SAP de Valencia de 18 de enero de 2003, en donde se concluye que «igual suerte desestimatoria debe de correr el alegato de que los acuerdos sociales son contrarios al pacto de sindicación de acciones, pues siendo éste un pacto que vincula a quienes lo adoptaron, no resulta oponible a la Sociedad»; SAP de Barcelona de 15 de febrero de 2001, que afirma «los pactos reservados entre los socios, no vinculan a la sociedad, pero ello no implica que no vincule a los contratantes en base al principio de libertad de pactos recogido en el art. $1255 \mathrm{CC}$; o SAP de Barcelona de 18 de noviembre de 1996, en donde se señala que «los Estatutos de la Sociedad Anónima y, concretamente, su artículo 9, que establece determinados límites a la libre transmisibilidad de las acciones, dentro de lo previsto por el artículo 63 de la Ley de Sociedades Anónimas no impiden pactos parasociales en la materia, inoponibles a la sociedad pero lícitos y eficaces entre los socios». 
otro modo, presentan una eficacia «inter partes», a diferencia de la eficacia «erga omnes» de los estatutos sociales. En buena lógica, esta afirmación conlleva importantes consecuencias en la práctica. Así, la eficacia de los pactos parasociales se limita, en principio, a los participantes en ellos, quedando al margen de los mismos la sociedad, los otros socios que no han tomado parte en los pactos y los terceros que entran en relación con aquella. De ahí que los acuerdos contenidos en un pacto parasocial no tengan relevancia alguna sobre el ejercicio de los derechos que corresponden al socio en cuanto tal, ni sobre la legitimidad de las obligaciones asumidas por los órganos sociales, con independencia de que el ejercicio de los derechos y la adopción de los acuerdos se haya realizado en cumplimiento o en violación de los pactos parasociales ${ }^{27}$. Por tanto, si varios socios se han comprometido a votar en un determinado sentido en junta como consecuencia de su participación en un sindicato de voto, pero, en el momento de la reunión, cualquiera de ellos vota en sentido contrario, este último voto es válido frente a la sociedad, la cual no podrá rechazar su voto. Es más, aquella eficacia «inter partes» también imposibilita la utilización de mecanismos o instrumentos del Derecho de sociedades para reclamar o forzar su cumplimiento o para sancionar su incumplimiento. Por lo tanto, no sería posible impugnar un acuerdo social adoptado en junta general en contravención de lo pactado en un sindicato de voto.

Puede afirmarse, por tanto, que la eficacia constituye el punto débil de los pactos parasociales. De hecho, esta cuestión y, en último término, los problemas que derivan del incumplimiento de estos pactos siguen siendo una de las materias candentes que preocupan a nuestra doctrina ${ }^{28}$, particularmente interesada en superar las dificultades que se derivan de su fragilidad. Sin embargo, la circunstancia de que los pactos parasociales estén ligados funcionalmente a la sociedad a que se refieren y de que le afecten indirectamente no puede servir de pretexto para recortar su alcance ${ }^{29}$. Si el pacto parasocial es válido, constituye «ley entre las partes» por aplicación del artículo 1091 del Código civil, lo que, a su vez, implica que quien está interesado en su cumplimiento puede servirse de cualquiera de los remedios contenidos en el ordenamiento jurídico para la defensa y protección de sus intereses contractuales $^{30}$. No está de más recordar que, ante el incumplimiento de un pacto parasocial, el resto de socios vinculados pueden exigir una indemnización

${ }^{27}$ Así, Pérez Moriones, A., Los sindicatos de voto para la junta general de accionistas de sociedad anónima, ob. cit., p. 287.

${ }^{28}$ Como ya apuntamos en su día -ver Pérez Moriones, A., Los sindicatos de voto para la junta general de accionistas de sociedad anónima, ob. cit., p. 430.

${ }^{29}$ Ver PAZ-Ares, C., «El "enforcement" de los pactos parasociales», Actualidad jurídica Uría Menéndez, núm. 5, 2003, p. 21.

${ }^{30}$ Tal y como concluye PAZ-ARES, C., «El "enforcement” de los pactos parasociales», ob. cit., p. 21. 
de daños y perjuicios al socio infractor ${ }^{31}$. Sin embargo, esta solución presenta ciertos problemas de carácter práctico, como la prueba del perjuicio o la determinación de la cuantía a satisfacer ${ }^{32}$. De ahí que para superar estas limitaciones, sea preferible la inserción de una cláusula penal en el pacto parasocial, mediante la cual predeterminar las consecuencias derivadas de su incumplimiento ${ }^{33}$. Igualmente, los intervinientes en un pacto parasocial pueden reforzar su cumplimiento mediante el recurso a negocios indirectos, dados los riesgos inherentes a la modalidad más simple de pacto parasocial, en la que son los propios socios participantes en el mismo quienes asumen el compromiso de cumplir lo pactado. Piénsese, entre otros, en el otorgamiento de un poder de representación a un síndico o gestor, en la cesión a este último de la posesión de las acciones o participaciones, en la transmisión fiduciaria de tales acciones o participaciones al gestor, en la constitución de una copropiedad, de un usufructo o de una prenda o, incluso, en la constitución de una sociedad holding a la que aportar las acciones o participaciones cuyos titulares se encuentran vinculados por el pacto parasocial ${ }^{34}$. Por último, como defendimos en su día en el marco concreto de los sindicatos de voto ${ }^{35}$, cabe el recurso a ciertos instrumentos procesales, como la ejecución por sentencia judicial, mediante la designación de un tercero en tanto representante del socio deudor, o la adopción de medidas cautelares. Se trata, en cualquier caso, de un «enforcement inter partes», cuando lo que buscamos es un «enforcement» mediante la utilización de mecanismos propios del Derecho de sociedades, es decir, un «enforcement» en relación a la sociedad ${ }^{36}$.

${ }^{31}$ Al respecto, consúltese STS de 19 de diciembre de 2000, Ref. Aranzadi núm. 10127.

32 En efecto, en el caso del incumplimiento de un sindicato de voto, que constituye una de las modalidades de pacto parasocial más celebrada, ¿cuánto vale el daño derivado de la adopción de un acuerdo con el voto favorable y determinante de algún miembro del sindicato, que en su día se comprometió a votar en un sentido contrario? O, igualmente, ¿cuánto vale la imposibilidad de haber tomado un acuerdo de trascendencia para la vida societaria y que tiene su origen en el incumplimiento de la obligación de ejercitar el derecho de voto atendiendo a la orientación previamente decidida en el sindicato de voto?

33 Sobre la utilización de cláusulas penales para superar las limitaciones que presenta la indemnización por daños y perjuicios en el marco de estos pactos, ver SSTS de 27 de septiembre de 1961, Ref. Aranzadi núm. 3029, o la más reciente de 26 de octubre de 2010, Ref. Aranzadi núm. 7601, así como RDGRN de 6 de junio de 1992, Ref. Aranzadi núm. 5728.

34 Sobre estos mecanismos, véase Pérez Moriones, A., Los sindicatos de voto para la junta general de accionistas de sociedad anónima, ob. cit., p. 488 y ss.

35 Ver Pérez Moriones, A., Los sindicatos de voto para la junta general de accionistas de sociedad anónima, ob. cit., p. 458 y ss.

${ }^{36}$ Tal y como lo denomina PAZ-ARES, C., «El "enforcement” de los pactos parasociales», ob. cit., pp. 21 y 30. 
Ahora bien, como hemos avanzado, la Propuesta de Código Mercantil dedica su artículo 213-2137 a los pactos parasociales. Esta previsión constituye una importante novedad, ya que el legislador regula por primera vez los pactos parasociales en general, sin limitarse al ámbito específico de las sociedades cotizadas. Sin embargo, esta propuesta de regulación no puede ser bien recibida. En efecto, atendiendo al párrafo primero del mencionado artículo, «los pactos celebrados entre todos o algunos socios, o entre uno o varios socios y uno o varios administradores al margen de la escritura social o de los estatutos, estén o no depositados en el Registro mercantil, no serán oponibles a la sociedad. Los acuerdos sociales adoptados en contra de lo previsto en los pactos serán válidos $\rangle^{38}$. Obsérvese que la Propuesta de Código no se limita a declarar la inoponibilidad de los pactos parasociales, tal y como ha sido habitual hasta la fecha, sino que viene a zanjar de forma indubitada las dudas existentes en relación con la posibilidad de impugnar acuerdos sociales adoptados en incumplimiento de un pacto parasocial, con independencia de que en éste hayan participado todos o algunos de los socios. De este modo, el mencionado precepto cierra la posibilidad de servirse del procedimiento de impugnación de acuerdos sociales a efectos de reforzar la eficacia de cualquier pacto parasocial, con independencia de cuál sea el sustrato personal vinculado por el mismo. Así, resulta discutible una previsión que, en caso de ser aprobada, deberá ser aplicada a «pactos celebrados entre todos o algunos socios, o entre uno o varios socios y uno o varios administradores», es decir, a todo pacto parasocial, sin discriminar si en el mismo han participado todos o algunos de los socios, cuando, como señalaremos en páginas posteriores, los pactos parasociales omnilaterales presentan unas particularidades que

37 «1. Los pactos celebrados entre todos o algunos socios, o entre uno o varios socios y uno o varios administradores al margen de la escritura social o de los estatutos, estén o no depositados en el Registro mercantil, no serán oponibles a la sociedad. Los acuerdos sociales adoptados en contra de lo previsto en los pactos serán válidos. 2. Son nulos aquellos pactos parasociales por los que uno o varios administradores de la sociedad se obliguen a seguir las instrucciones de socios o de terceros en el ejercicio de su cargo. 3. Quien hubiere incumplido un pacto parasocial deberá indemnizar los daños y perjuicios causados y asumir las demás consecuencias previstas en el pacto. 4. Lo dispuesto en este artículo será de aplicación a los protocolos familiares, haya o no constancia registral de su existencia o contenido».

${ }^{38}$ El art. 213-31 de la Propuesta de Código Mercantil sigue la orientación adoptada por el art. 17 del Código de Sociedades Comerciales portugués, a tenor del cual «1. Os acordos parassociais celebrados entre todos ou entre alguns sócios pelos quais estes, nessa qualidade, se obriguem a uma conduta não proibida por lei têm efeitos entre os intervenientes, mas com base neles não podem ser impugnados actos da sociedade ou dos sócios para com a sociedade. 2. Os acordos referidos no número anterior podem respeitar ao exercício do direito de voto, mas não à conduta de intervenientes ou de outras pessoas no exercício de funções de administração ou de fiscalização. 3. São nulos os acordos pelos quais um sócio se obriga a votar: a) Seguindo sempre as instruções da sociedade ou de um dos seus órgãos; b) Aprovando sempre as propostas feitas por estes; c) Exercendo o direito de voto ou abstendo-se de o exercer em contrapartida de vantagens especiais». 
justifican un tratamiento diferenciado. Por el contrario, el legislador parece limitar los mecanismos dirigidos a reforzar la eficacia de los pactos parasociales a aquellos específicos del Derecho de contratos, ya que el párrafo tercero del artículo 231-26 señala que «(Q)uien hubiere incumplido un pacto parasocial deberá indemnizar los daños y perjuicios causados y asumir las demás consecuencias previstas en el pacto». Esta declaración resulta innecesaria por obvia. Pero, además, no satisface los problemas que se derivan de la fragilidad inherente al pacto parasocial. En efecto, quien participa en un pacto parasocial pretende que todos los socios que han participado en él lo respeten, por más que, en caso de incumplimiento, reciba una indemnización por los daños y perjuicios causados, la cual difícilmente satisfará su interés principal, que no es otro que el cumplimiento del pacto.

\section{LA NECESARIA REVISIÓN DE LA EFICACIA DE LOS PAC- TOS PARASOCIALES}

\subsection{La situación en ordenamientos jurídicos de nuestro entorno}

La interpretación tradicional de la eficacia de los pactos parasociales debe ser objeto de revisión tras haberse dictado ciertas resoluciones judiciales que adoptan una solución opuesta a aquella. Como hemos señalado, atendiendo a la tesis tradicional, los pactos parasociales presentan una eficacia meramente «inter partes» y no «erga omnes», con las consecuencias ya mencionadas. Sin embargo, aquellas resoluciones han reconocido eficacia societaria a determinados pactos parasociales, siempre, desde luego, que en ellos concurran ciertas circunstancias. No se trata, por tanto, de una revisión absoluta de la doctrina tradicional o, dicho de otro modo, no cabría generalizar la solución adoptada en tales resoluciones a cualquier pacto parasocial, sino únicamente a algunos pactos parasociales. En cualquier caso, es necesario subrayar cómo esta revisión de la eficacia de los pactos parasociales no se ha producido exclusivamente en nuestro país, sino que también se ha llevado a cabo en ordenamientos jurídicos de nuestro entorno, tradicionalmente proclives a la utilización de pactos parasociales. En efecto, primero en Alemania y, posteriormente, en Austria y en Italia se han dictado resoluciones judiciales favorables al reconocimiento de eficacia societaria a los pactos parasociales de todos los socios o pactos parasociales omnilaterales ${ }^{39}$.

${ }^{39} \mathrm{Al}$ respecto, ver Pérez Millán, D., «Presupuestos y fundamento jurídico de la impugnación de acuerdos sociales por incumplimiento de pactos parasociales», $R D B B$, núm. 117, 2010, p. 242; así como el detallado análisis de Noval PATO, J., Los pactos omnilaterales: su oponibilidad a la sociedad. Diferencias y similitudes con los estatutos y los pactos parasociales, ob. cit., p. 59 y ss. 
En este sentido, en sentencia de fecha 20 de enero de $1983^{40}$, el BGH admite la impugnación de un acuerdo social que incumplía un pacto ajeno a los estatutos y en el que participaban todos los socios por considerar que tales pactos conforman el ordenamiento de la persona jurídica, siempre que los obligados por dichos pactos continúen siendo los únicos miembros de la sociedad. Por lo que a nosotros nos interesa, es necesario tener presente que la fundamentación de la decisión no fue otra que razones de economía procesal, al entender que carece de sentido que para eliminar un acuerdo social que infringe un pacto omnilateral no se admita la impugnación societaria del mismo, cuando al mismo resultado se puede llegar, con mayores costes, utilizando los instrumentos que proporciona el Derecho de obligaciones y contratos. Igualmente, en sentencia de 27 de octubre de $1986^{41}$, el BGH confirma su posición favorable al reconocimiento de efectos societarios a los pactos parasociales. En este caso, los socios se habían obligado a condicionar la eficacia del acuerdo de destitución del socio-administrador al consentimiento del propio socio afectado, a pesar de lo cual la junta general decide cesarlo incumpliendo lo acordado en el pacto parasocial. El BGH estima el recurso ante él interpuesto, aunque se limita a invocar la sentencia de 20 de enero de 1983. Por último, en sentencia de 15 de marzo de $2010^{42}$, el BGH vuelve a reconocer efectos societarios a un pacto parasocial, si bien el conflicto se plantea de forma inversa a como habitualmente se suscita. En este caso, todos los socios reunidos en junta general adoptan unánimemente el acuerdo de percibir en tanto reembolso el valor nominal de sus participaciones, en caso de ser excluidos de la sociedad, aunque en los estatutos sociales se prevé una valoración superior. Dicho acuerdo no es elevado a escritura pública ni inscrito en el Registro Mercantil. En el momento en que se acuerda expulsar a un socio y reintegrarle el valor nominal de sus participaciones, aquél impugna tanto el acuerdo como la valoración de dichas participaciones, con base en que tal valoración era contraria a los estatutos sociales. Obsérvese, por tanto, que en este caso, el socio impugna un acuerdo que respeta el pacto parasocial, pero que es contrario a los estatutos sociales. En este caso, el BGH declara la validez del acuerdo porque no incidía sobre una norma de organización, sino sobre una obligación de la sociedad frente a un socio excluido. Como veremos en páginas posteriores, la Audiencia Provincial de Madrid, en sentencia de fecha 16 de noviembre de 2012 -asunto «Prevención Outsourcing, S.L.»-, se pronuncia en relación con un asunto similar, aunque de una forma mucho más terminante, dadas las circunstancias concurrentes en el caso.

A su vez, la influencia de la jurisprudencia y de la doctrina alemana ha conducido a la revisión de la cuestión relativa a la eficacia de los pactos para-

${ }^{40}$ BGH de 20 de enero de 1983, NJW, 1983, p. 1911.

${ }^{41}$ BGH de 27 de octubre de 1986, NJW, 1987, p. 1890 y ss.

${ }^{42}$ BGH de 15 de marzo de 2010. 
sociales tanto en Austria como en Italia ${ }^{43}$. Así, en sentencia de 5 de diciembre de 1995, el OGH austríaco reconoce cierta eficacia a los pactos parasociales. En efecto, aun cuando aquel subraya que los pactos parasociales no inciden directamente en la esfera societaria y, como consecuencia, no pueden fundamentar la impugnación de un acuerdo social, sostiene que los pactos parasociales pueden representar un instrumento que permita concretar el deber de fidelidad del socio. Esta afirmación permite que los pactos parasociales puedan ser invocados para impugnar un acuerdo social ${ }^{44}$, tal y como sostendremos en páginas posteriores. Años más tarde, el 26 de agosto de 1999, el OGH se pronuncia en relación con un supuesto similar al analizado por el BGH alemán en sentencia de fecha 27 de octubre de 1986. En este caso, la junta general de una sociedad adopta el acuerdo de cesar como administrador a un socio, a pesar de un pacto extraestatutario de todos los socios en el que se acordaba que un socio no podía ser cesado en contra de su voluntad. Pues bien, el OGH recuerda que la infracción de los pactos parasociales puede constituir una vulneración del deber de fidelidad y admite que, en algunos casos, el incumplimiento de un pacto parasocial puede motivar la impugnación de un acuerdo social, aun cuando ni esta ampliación de los motivos de impugnación responde exclusivamente a razones de economía procesal ${ }^{45}$, ni tampoco cualquier pacto omnilateral debe integrar de forma automática el ordenamiento societario. De hecho, el OGH condiciona la eficacia societaria de un pacto parasocial a que en el mismo hayan participado todos los socios y a que se trate de sociedades con una marcada estructura personalista, debido a su número reducido de socios y a la relevancia que se otorga a la presencia de cada uno de los socios dentro de la sociedad. Este criterio es reiterado posteriormente por el OGH en su sentencia de fecha 24 de enero de 2001, en la que igualmente subraya las dificultades que plantea trasladarlo al ámbito de las sociedades anónimas.

Por otra parte, y por lo que respecta al ordenamiento italiano, resulta obligado destacar un laudo arbitral de 7 de junio de $2000^{46}$, que se pronuncia en relación con un pacto parasocial celebrado por todos los socios, mediante el cual se regula el ejercicio del derecho de adquisición preferente de participaciones sociales previsto en los estatutos sociales. Al respecto, el colegio arbitral reconoce que el pacto parasocial posee eficacia para integrar la cláusula estatutaria y que sólo desde una concepción exasperadamente realista

${ }^{43}$ Véase Noval Pato, J., Los pactos omnilaterales: su oponibilidad a la sociedad. Diferencias y similitudes con los estatutos y los pactos parasociales, ob. cit., p. 64 y 65.

${ }_{44}$ Así, Noval Pato, J., Los pactos omnilaterales: su oponibilidad a la sociedad. Diferencias y similitudes con los estatutos y los pactos parasociales, ob. cit., p. 64.

${ }^{45}$ A diferencia de la sentencia del BGH de 20 de enero de 1983.

46 Véase Giur. it., 2001, p. 1208 y ss. 
de la persona jurídica puede justificarse la inoponibilidad a la sociedad de un pacto parasocial suscrito por todos los $\operatorname{socios}^{47}$.

\subsection{El estado de la cuestión en el ordenamiento español}

\subsubsection{Antecedentes: la orientación jurisprudencial favorable al reconoci- miento de eficacia societaria a los pactos parasociales de todos los socios o pactos parasociales omnilaterales}

Como hemos avanzado, el artículo 29 LSC se limita a declarar la inoponibilidad frente a la sociedad de los pactos que se mantengan reservados entre los socios, pero no contiene una definición de qué debe entenderse por «pacto reservado». Ante esta carencia, la doctrina española mayoritaria sostiene que pacto reservado es todo pacto no incluido en los estatutos; afirmación de la que se deduce que si todo pacto no incluido en los estatutos sociales es un pacto reservado, todo pacto no incluido en los estatutos sociales es inoponible a la sociedad. En buena lógica, la falta de inclusión de los pactos parasociales determina su calificación como pactos reservados y, por tanto, su inoponibilidad a la sociedad. Sin embargo, la cuestión relativa a la eficacia de los pactos parasociales se ha replanteado con intensidad en nuestro ordenamiento con ocasión de las últimas sentencias dictadas por el Tribunal Supremo sobre esta materia, aunque no podemos olvidar que aquel ya se había pronunciado al respecto hace unos años de modo favorable a la oponibilidad frente a la sociedad de ciertos pactos parasociales, en concreto, en los pactos parasociales en los que han intervenido todos los socios ${ }^{48}$. Ahora bien, como acertadamente fue apuntado, «tanto la doctrina como la judicatura han alcanzado la referida conclusión de una manera más bien intuitiva, con una gran dosis de intuicionismo, voluntarismo y hasta decisionismo, recurriendo a argumentos escasamente elaborados o a expedientes excesivamente genéricos $\rangle^{49}$. Quizás

47 Sobre este asunto, véase Noval PATO, J., Los pactos omnilaterales: su oponibilidad a la sociedad. Diferencias y similitudes con los estatutos y los pactos parasociales, ob. cit., p. 65, nota núm. 58, con ulteriores referencias bibliográficas.

${ }_{48}$ Ver Pérez Moriones, A., Los sindicatos de voto para la junta general de accionistas de sociedad anónima, ob. cit., p. 483 y ss.; y PAZ-ARES, C., «El "enforcement" de los pactos parasociales», ob. cit., p. 33 y ss. Rotundamente en contra de esta interpretación, MAdRIDEJos FernándeZ, J. Ma ., «La inoponibilidad de los pactos parasociales frente a la sociedad. Comentario a la Sentencia del Tribunal Supremo de 6 de marzo de 2009», ob. cit., pp. 296, 298, 299 y 300, en donde concluye de forma claramente errónea que «(L) o sostenido por estos autores es tanto como afirmar que el tribunal supremo establece la anulación de todos los acuerdos que impliquen violación de un pacto parasocial, aunque ignora que lo hace por esta causa. En realidad, es lo contrario, ni siquiera se planteaba hasta fechas recientes la posibilidad de que el incumplimiento de un pacto parasocial pudiese fundar la impugnación del acuerdo social».

49 Así, PAZ-Ares, C., «El "enforcement" de los pactos parasociales», ob. cit., p. 33. En un sentido similar, REDOndo Trigo, F., «Los pactos parasociales y la impugnación de 
esta circunstancia pueda explicar algunos de los comentarios vertidos tras los últimos pronunciamientos dictados por el Tribunal Supremo en los años 2008 y 2009; comentarios de los que, desde luego, discrepamos.

Así, en la sentencia de 24 de septiembre de $1987^{50}$-asunto «Hotel Atlantis Playa»-, el Alto Tribunal se sirve de la doctrina del levantamiento del velo. En el pacto parasocial origen de la disputa el socio único de la mercantil «Hotel Atlantis Playa, S.A.» reconoce que el 13\% del capital social es propiedad de doña Jeanne Antoniette B., aunque formalmente es él quien aparece como único socio «por razones convenientes a la sociedad». A su vez, el artículo 14 de los estatutos sociales exige para la existencia de acuerdo en las juntas generales, «el voto favorable de dos socios como mínimo, sin que pueda estimarse existente el adoptado con el voto de un solo socio, aunque en él se reúnan la mayoría de las acciones a no ser en los casos permitidos en que la sociedad tenga un solo socio». La celebración de junta general extraordinaria, a la que acude el socio «único», que es quien adopta los correspondientes acuerdos sociales, determina la impugnación de dichos acuerdos por doña Jeanne Antoinette B., con base en el incumplimiento del artículo 14 de los estatutos sociales, ya que la sociedad considera que únicamente existe un solo socio, porque el pacto parasocial no le es oponible. Pues bien, el Tribunal Supremo recuerda que «(E)n varias sentencias, y en conformidad con la mejor doctrina, esta Sala no ha vacilado en apartar el artificio de la Sociedad anónima para decidir los casos según la realidad, de modo que “...en el caso ahora justiciable, la aparatosa convocatoria mediante los anuncios del artículo 53 de la Ley, de una Junta General Extraordinaria de Sociedad anónima constituida reconocidamente por dos únicos socios que se hallan ligados por los pactos recordados, no puede servir, en perjuicio de la impugnante que es uno de ellos dos, para que el otro se evada de estos pactos que constituyen, artículo 1091 del Código Civil, la particular ley de los contratantes, la que no puede quedar, artículo 1256, al arbitrio de uno de ellos"”».

Con posterioridad, el Tribunal Supremo reconoce eficacia societaria a un pacto parasocial en las sentencias del asunto «Munaka»-SSTS de 26 de febrero de 1991 y de 10 de febrero de $1992^{51}$. En la primera, el Tribunal Supremo se pronuncia a favor de la validez de un pacto parasocial, con base en el cual los cuatro accionistas de la sociedad «Munaka, S.A.»-madre, dos hermanos y mujer de uno de éstos- se dividen todas las propiedades comunes de dos hermanos y se obligan todos ellos a reducir el capital social de cara a una posterior disolución y liquidación de la misma. En efecto, aquél concluye que «....aunque se estimase que tal acuerdo no fue tomado en Junta

acuerdos sociales por su infracción tras la reciente jurisprudencia del Tribunal Supremo», $R C D I, 2009$, p. 2685, que califica de «artificiosas» las soluciones ofrecidas por tales sentencias.

${ }^{50}$ STS de 24 de septiembre de 1987, Ref. Aranzadi núm. 6194.

51 SSTS de 26 de febrero de 1991, Ref. Aranzadi núm.1600; y de 10 de febrero de 1992, Ref. Aranzadi núm. 1204. 
General de accionistas de "Munaka, S. A." y que, por tanto, no es un acuerdo social, es claro que concurriendo en el mismo los requisitos esenciales para la validez de los contratos del art. 1261 del Código Civil, tal convenio tiene fuerza obligatoria entre quienes lo suscribieron y deben ser cumplidos a su tenor (art. 1091), dando cumplimiento no sólo a lo expresamente pactado, sino también a todas las consecuencias que, según su naturaleza, sean conformes a la buena fe, al uso y a la Ley...». Con todo, la existencia del mencionado pacto parasocial no constituye obstáculo para que, con ocasión de la celebración de una junta general extraordinaria, a la que falta uno de los hermanos, los otros tres accionistas acuerden la ampliación del capital social. El accionista ausente impugna aquel acuerdo social con base en que la junta general extraordinaria se había celebrado con abuso de derecho y mala fe, causando lesión a los intereses de la sociedad en beneficio de uno o varios accionistas. Por su parte, en la segunda de las sentencias, el Tribunal Supremo fundamenta su decisión en la lesión de los intereses de la sociedad, que se ha producido como consecuencia de la actuación abusiva llevada a cabo por varios de los accionistas de la sociedad ${ }^{52}$. El Alto Tribunal también alude a la celebración de una «suerte» de junta universal, de modo que, según esta interpretación, el pacto parasocial constituiría un acuerdo informal de junta universal, el cual vincularía a la sociedad por ser un acuerdo societario. Sin embargo, a nuestro juicio, el recurso a la ficción de la celebración de una junta universal resulta, a todas luces, discutible ${ }^{53}$. En efecto, no consta en sentido

52 En relación con esta actuación, el Tribunal Supremo entiende que, efectivamente, «...la lesión de los intereses de la sociedad, en beneficio de uno o varios accionistas (que es una de las causas de impugnación contempladas en el precepto invocado) puede producirse mediante acuerdos sociales adoptados con la intervención de las circunstancias tipificadoras del abuso de derecho (subjetiva, de intención de perjudicar o falta de una finalidad seria, y objetiva, de anormalidad en el ejercicio del mismo), que es lo ocurrido en el presente supuesto litigioso, como acertadamente ha entendido la sentencia recurrida, no obstante la parvedad de su argumentación...». A continuación, en la sentencia se apunta que «...la más elemental buena fe negocial e incluso societaria (dado el ya dicho carácter estrictamente familiar de la sociedad) aconsejaba, antes de la celebración de la sedicente Junta General Extraordinaria antes referida, esperar el resultado del aludido proceso, al caber la posibilidad de que se declarara la plena validez y eficacia del repetido documento privado de fecha 17-10-1985 y se condenara a los tres demandados disidentes al cumplimiento del mismo, como así ocurrió con posterioridad mediante Sentencia de la Sala de lo Civil de la (entonces) Audiencia Territorial de Bilbao, de fecha 27-12-1988, confirmada por Sentencia de esta Sala Primera del Tribunal Supremo, de fecha 26-2-1991 (Recurso de casación núm. 514/1989), cuya ejecución (de la referida sentencia firme) se vería seriamente dificultada, cuando no imposibilitada, si se mantuviera la validez del acuerdo social aquí impugnado, el cual fue adoptado, como ya se tiene dicho, en abierta y franca contravención de lo que los cuatro únicos accionistas de la sociedad (en una especie de Junta universal) tenían previamente convenido en el tantas veces repetido documento privado de fecha 17-10-1985».

${ }^{53}$ Ver, al respecto, las observaciones de PAZ-Ares, C., «El "enforcement" de los pactos parasociales», ob. cit., p. 34; o de Noval Pato, J., Los pactos omnilaterales: su oponibilidad a la sociedad. Diferencias y similitudes con los estatutos y los pactos parasocia- 
estricto dicha reunión con el carácter de tal ni, mucho menos, se ha levantado acta de la junta con inclusión de los asuntos objeto de la misma o se ha procedido a su inscripción en el Registro Mercantil, por lo que los acuerdos en ella adoptados no son oponibles frente a terceros. Por el contrario, el argumento determinante de la decisión adoptada por el Tribunal Supremo no es otro que la alegación de la lesión del interés social en beneficio de uno o varios accionistas o de terceros con la concurrencia de elementos tipificadores del abuso del derecho.

\subsubsection{El estado de la cuestión tras las sentencias dictadas por el Tribunal Supremo en relación con el grupo «Kurt Konrad y Cía, S.A.»}

La orientación jurisprudencial favorable a la posibilidad de impugnar acuerdos sociales en los que se ha incumplido lo pactado en un pacto parasocial queda truncada, a nuestro juicio sólo aparentemente, en el momento en que el Tribunal Supremo dicta una serie de sentencias en los años 2008 y 2009. Nos estamos refiriendo, por orden cronológico, a la sentencia de 10 de diciembre de $2008^{54}$-asunto «Turística Konrad Hidalgo, S.L.»-, a la sentencia de 5 de marzo de $2009^{55}$-asunto «Kurt Konrad y Cía, S.A.»-, y a dos sentencias, de fecha 6 de marzo de $2009^{56}$-asunto «Camanchaca, S.L.» y asunto «Turística Konrad Hidalgo, S.L.»-. Todas ellas tienen su origen remoto en un pacto parasocial de fecha 23 de junio de 1997, celebrado en el marco del grupo «Kurt Konrad y Cía, S.A.», formado a su vez por varias sociedades, cuyas acciones y participaciones se encontraban repartidas de forma desigual entre dos grupos familiares. Mediante el mencionado pacto parasocial los dos grupos familiares propietarios de las sociedades «Turística Konrad Hidalgo, S.L.» y «Camancha, S.L» se comprometen a votar afirmativamente en

les, ob. cit., pp. 89 y 90. No así para SAnchez Álvarez, M., «Comentario a la Sentencia de 5 de marzo de 2009», ob. cit., p. 1380, el cual prefiere esta solución, es decir, calificar el pacto como acuerdo de junta general universal, siempre que concurran ciertas circunstancias: «...cuando se está ante un pacto que versa sobre materias que sean propias del funcionamiento de la sociedad, incluidos algunos aspectos de las relaciones entre socio y sociedad, cuando el acuerdo tiene un contenido concreto, claro y directamente ejecutable -lo que no quiere decir que sea totalmente completo - que haga realmente innecesario un ulterior acuerdo social, salvo por razones puramente formales o porque condiciones expresamente establecidas en dicho pacto o porque así se haya establecido en el mismo».

${ }^{54}$ STS de 10 de diciembre de 2008, Ref. Aranzadi núm. 17 (2009).

55 STS de 5 de marzo de 2009, Ref. Aranzadi núm. 1633.

56 SSTS de 6 de marzo de 2009, Ref. Aranzadi núm. 2793 y 2794. Sobre estas sentencias, pueden consultarse los comentarios de MAdridEJos FernÁndez, J. M ${ }^{\mathrm{a}}$, «La inoponibilidad de los pactos parasociales frente a la sociedad. Comentario a la Sentencia del Tribunal Supremo de 6 de marzo de 2009», ob. cit., p. 291 y ss.; y Ruz-CÁmara, J. y ToRREGROSA, E., «Nuevamente a vueltas con la eficacia societaria de los pactos parasociales (A propósito de las SSTS de 6 de marzo de 2009)», Actualidad jurídica Uría Menéndez, núm. 24, 2009, p. 65 y ss. 
las juntas generales para lograr una determinada composición del órgano de administración y se fija una especie de derecho de representación proporcional en el consejo de administración de «Turística Konrad Hidalgo, S.L.», con la finalidad de establecer temporalmente un principio de cogestión de las sociedades participadas hasta que la coyuntura económica permita la escisión del patrimonio de tales entidades. Precisamente, el incumplimiento en distintas ocasiones del contenido del pacto parasocial conduce a determinados socios de dichas sociedades a impugnar los acuerdos sociales adoptados en contravención del pacto. Permítasenos, por lo tanto, un análisis conjunto de las sentencias mencionadas, al tener todas ellas por objeto el incumplimiento en distintas circunstancias del mismo pacto parasocial y adoptar los fallos el Tribunal Supremo con base en dos grandes líneas argumentales: por un lado, la relativa a los cauces previstos legalmente para la impugnación de acuerdos sociales; y, por otro lado, la corrección que realiza de la interpretación sostenida por la parte recurrente en relación con la doctrina contenida en las sentencias de 27 de septiembre de 1987 -asunto «Hotel Atlantis Playa»-y de 10 de febrero de 1992 -asunto «Munaka»-.

Así, ya en la primera de las sentencias dictadas en el marco de los conflictos planteados en el grupo «Konrad y Cía, S.A.» de 10 de diciembre de 2008, el Alto Tribunal recuerda los cauces legalmente previstos a efectos de la impugnación de acuerdos sociales, apuntando, igualmente, que la parte recurrente no ha alegado ni norma legal infringida, ni vulneración de los estatutos sociales ni lesión de los intereses de la sociedad; declaración que es reiterada en las posteriores sentencias de 5 de marzo y de 6 de marzo de 2009. La importancia práctica del cumplimiento de esta exigencia resulta evidente, puesto que de su satisfacción dependerá en buena medida el éxito de la impugnación realizada. En efecto, la mera alegación del incumplimiento de un pacto parasocial no es suficiente a efectos de impugnar un acuerdo social adoptado en contravención del mismo, pero sí puede serlo la alegación de que la adopción de un acuerdo social incumpliendo lo convenido en un pacto parasocial conlleva una infracción de una norma legal, una vulneración de los estatutos sociales o una lesión de los intereses sociales, siempre, desde luego, que concurran el resto de circunstancias exigidas para el éxito de tal impugnación. A nuestro juicio, este argumento, que ha sido objeto de ciertas críticas $^{57}$, presenta como ventajas la claridad y la seguridad que conlleva: ya no habrá que servirse de argumentos poco elaborados o expedientes excesivamente genéricos ni tampoco será necesario actuar con intuicionismo,

${ }^{57}$ Así, Sáez Lacave, Mª I., «Los pactos parasociales de todos los socios en Derecho español. Una materia en manos de los jueces», Indret, 2009, núm. 3, p. 20, que señala que «(N)ada habría que objetar si lo que se pretende es deslegitimar de manera más firme y recta la deslealtad que entraña la infracción del pacto parasocial al amparo de la normativa societaria. Lo que sucede es que lo que parece perseguirse es justamente lo contrario, esto es, desautorizar de raíz las fórmulas que los jueces venían aplicando para otorgar eficacia a los pactos parasociales en la esfera societaria». 
voluntarismo o decisionismo ${ }^{58}$. El Tribunal Supremo nos indica la vía que hay que tomar en caso de pretender la impugnación de un acuerdo social en contravención de los compromisos adoptados por la participación en un pacto parasocial. El necesario -rectius, obligado- fundamento en alguno de los supuestos previstos en el art. 204 LSC facilitará el éxito de tales demandas, siempre, desde luego, que se satisfagan los requisitos exigidos en este precepto.

El segundo argumento del que se sirve el Tribunal Supremo y que presenta indudable interés es la corrección que realiza acerca de la interpretación de las sentencias de 27 de septiembre de 1987 -asunto «Hotel Atlantis Playa»-y de 10 de febrero de 1992 -asunto «Munaka»-. Así, en los procedimientos seguidos como consecuencia de los conflictos suscitado en el grupo «Konrad y Cía» se sostiene de parte que la doctrina jurisprudencial permite impugnar un acuerdo societario -bien de junta, bien de consejo de administración - contrario a un pacto parasocial por constituir una ilegalidad su vulneración, al ser de obligado cumplimiento para quienes han tomado parte en el mismo ${ }^{59}$. Sin embargo, ni de la sentencia de 27 de septiembre de 1987 ni de la de 10 de febrero de 1992 se infiere esta conclusión. En efecto, el Tribunal Supremo puntualiza que «la verdadera doctrina contenida en las sentencias de 24 de septiembre de 1987 y 10 de febrero de 1992, es decir, las dos citadas en el encabezamiento del motivo que sí guardan estrecha relación con la cuestión planteada, es que la contravención por los órganos sociales de unos pactos privados entre los socios, sobre todo si éstos son todos los socios, puede determinar la nulidad de lo acordado por resultar en definitiva contrario a la ley, a los estatutos o al interés social ${ }^{60}$. En este sentido, como acertadamente corrige aquél, «(L)a Sentencia de 24 de septiembre de 1987 estima la impugnación del acuerdo social por violación del art. 14 de los Estatutos videntes en la fecha en que se adoptó el acuerdo, con independencia de que discurra acerca de los pactos existentes entre los socios al respecto de la legitimación de la impugnante y aplique la doctrina denominada del "levantamiento del velo"; y la Sentencia de 10 de febrero de 1992...razona, frente al alegato del motivo de que el abuso del derecho en que se funda la sentencia de apelación no se encuentra entre las posibles causas de impugnación de acuerdos sociales que prevé el art. 67 de la LSA de 17 de junio de 1951 SIC (del que es trasunto el actual 115 de la LSA 1989), que, "la lesión de los intereses de la sociedad en beneficio de uno o varios accionistas (que es una de las causas de impugnación contempladas en el precepto invocado) puede producirse mediante acuerdos sociales adoptados con la intervención

${ }^{58}$ Nos servimos de las expresiones utilizadas en su día por PAZ-Ares, C., «El "enforcement" de los pactos parasociales», ob. cit., p. 33, a las que ya nos hemos referido en páginas anteriores.

59 Véanse SSTS de 10 de diciembre de 2008, Ref. Aranzadi núm. 17 (2009); y de 6 de marzo de 2009, Ref. Aranzadi núm. 2793 y 2794.

${ }^{60}$ Ver STS de 5 de marzo de 2009, Ref. Aranzadi núm. 1633. 
de las circunstancias tipificadotas del abuso del derecho (subjetiva, de intención de perjudicar o falta de una finalidad seria, y objetiva, de anormalidad en el ejercicio del mismo), que es lo ocurrido en el presente supuesto litigioso, como acertadamente ha entendido la sentencia recurrida" $>{ }^{61}$. Declaraciones similares son reproducidas en las dos sentencias dictadas con fecha 6 de marzo de 2009, en las que, en idénticos términos, se afirma que «(L)a de 24 de septiembre de 1987 declaró no haber lugar al recurso de casación interpuesto contra una sentencia que había anulado los acuerdos impugnados, pero lo hizo por la razón de ser éstos contrarios a los estatutos. Y la ratio decidendi de la sentencia de 10 de febrero de 1992 no fue otra que la demostración de una lesión de los intereses de la sociedad en beneficio de uno o varios accionistas». En efecto, a la hora de reconocer eficacia societaria a pactos parasociales, el Tribunal Supremo se sirve de la doctrina del levantamiento del velo en la sentencia de 24 de septiembre de 1987 y de la lesión del interés social en la sentencia de fecha 10 de febrero de 2010, pero de ninguna de ellas se puede concluir que el Alto Tribunal admita la impugnación de un acuerdo societario contrario a un pacto parasocial con base exclusivamente en el argumento de que su vulneración constituye una ilegalidad. Es cierto que el resultado final es el mismo, puesto que el Tribunal Supremo ampara a quienes impugnan los respectivos acuerdos sociales adoptados en contravención de los respectivos acuerdos parasociales ${ }^{62}$. Sin embargo, como hemos señalado, las argumentaciones de las que el citado tribunal se sirve no son coincidentes, con independencia de la mayor o menor entidad de las mismas.

En definitiva, la trascendencia de estas sentencias se encuentra fuera de toda duda, ya que el Tribunal Supremo resuelve el interrogante de si el incumplimiento de un pacto parasocial celebrado por todos los socios constituye causa para anular los acuerdos impugnados. Aquel rechaza la posibilidad de anular un acuerdo social con base en la mera alegación del incumplimiento de un pacto parasocial. Con todo, también señala el camino que ha de seguirse en caso de pretender la anulación de acuerdos sociales adoptados contraviniendo un pacto parasocial, al admitir que el incumplimiento del pacto parasocial puede subsumirse en alguno de los supuestos de impugnación previstos en el antiguo artículo 115 LSA 1989. Por tanto, de las últimas decisiones adoptadas por el Tribunal Supremo no se puede concluir que este último niegue de plano la posibilidad de impugnar un acuerdo social por violación de los pactos parasociales suscritos por la

${ }^{61}$ Así, STS de 10 de diciembre de 2008, Ref. Aranzadi núm. 17 (2009).

${ }^{62}$ No compartimos la crítica a esta argumentación realizada por SÁEz LACAVE, Ma . I., «Los pactos parasociales de todos los socios en Derecho español. Una materia en manos de los jueces», ob. cit., p. 20, que sostiene que «(L)o importante, salvo para los nominalistas a ultranza, no es lo que se ha dicho, sino lo que se ha hecho. Y no es dudoso que el Tribunal Supremo ha garantizado el enforcement del pacto parasocial en la esfera societaria, es decir, ha amparado a quienes, impugnando un acuerdo social, solicitaban que no se diera eficacia "societaria" a una infracción del acuerdo parasocial». 
totalidad de los socios de una sociedad, tal y como ha sido sostenido por cierto sector doctrinal ${ }^{63}$. Se trata, presumimos, de una interpretación basada en una lectura precipitada de las mencionadas sentencias. Por el contrario, el Tribunal Supremo se limita a rechazar el incumplimiento del pacto parasocial en sí mismo considerado a efectos de la impugnación de los acuerdos sociales adoptados en contravención del mismo, pero reconduce tal impugnación a la necesaria subsunción en alguno de los supuestos previstos en el artículo 115 LSA 1989 -actual art. 204 LSC-. Es decir, aquel no rechaza la posibilidad de impugnar un acuerdo social adoptado en contravención de lo acordado en un pacto parasocial, sino la impugnación del mismo basada exclusivamente en la mera infracción del pacto ${ }^{64}$.

\subsubsection{Una última vuelta de tuerca acerca de la eficacia societaria de los} pactos parasociales de todos los socios o pactos omnilaterales: la sentencia de la Audiencia Provincial de Madrid de 16 de noviembre de 2012

Recientemente, la Sección $28^{\text {a }}$ de la Audiencia Provincial de Madrid se ha pronunciado en relación con la materia objeto de este trabajo en sentencia de fecha 16 de noviembre de $2012^{65}$-asunto «Prevención Outsourcing, S.L.»)-, aunque, como hemos avanzado en páginas anteriores, en este caso el conflicto se plantea de manera inversa a la que habitualmente se suscita. Así, en este caso la impugnación de acuerdos sociales no tiene origen en el incumplimiento de un pacto parasocial. Precisamente, este último es respetado a la hora de adoptar acuerdos en junta, pero, posteriormente, uno de los socios procede a la impugnación de tales acuerdos -en los que, téngase presente, se ha respetado el contenido del pacto parasocial-, alegando el incumplimiento de los estatutos sociales. Resulta, por tanto, obligado subrayar el paralelismo entre este asunto y el resuelto por el BGH en sentencia de fecha 15 de marzo de 2010.

La sentencia de 16 de noviembre de 2012 tiene por objeto el problema que se suscita en el marco de una sociedad de responsabilidad limitada, «Prevención Outsourcing, S.L.», cuyo capital social se encuentra repartido entre dos socios, «Suceed Investments, S.L.» e «Inversiones y Patrimonios Eca Global, S.A.», de forma desigual -sesenta y cuarenta por ciento, respectiva-

${ }^{63}$ Tal y como, por ejemplo, han entendido MadrideJos FernÁndez, J. Mª, «La inoponibilidad de los pactos parasociales frente a la sociedad. Comentario a la Sentencia del Tribunal Supremo de 6 de marzo de 2009», ob. cit., p. 296 y ss.; o SANChez Álvarez, M., «Comentario a la Sentencia de 5 de marzo de 2009», ob. cit., p. 1368.

${ }^{64}$ Ver, igualmente, REDONDO TRIGO, F., «Los pactos parasociales y la impugnación de acuerdos sociales por su infracción tras la reciente jurisprudencia del Tribunal Supremo», ob. cit., p. 2685.

${ }^{65}$ Sentencia de la Sección $28^{\text {a }}$ de la Audiencia Provincial de Madrid de 16 de noviembre de 2012, JUR 2013/5173. 
mente-. En el artículo 12 de los estatutos sociales se prevén unas mayorías reforzadas para la adopción de acuerdos sociales -con carácter general, un voto favorable de los $2 / 3$ del capital social y de $3 / 4$ en caso de operación acordeón-. Sin embargo, en un pacto parasocial, ambos socios deciden establecer la exigencia del voto favorable del sesenta por ciento del capital social para, entre otros asuntos, aprobar la ampliación y reducción del capital, proceder a cualquier modificación estatutaria o decidir el nombramiento y cese de administradores. El pacto se respeta sin problemas en dos juntas generales consecutivas, a pesar de lo cual el socio minoritario las impugna, alegando el incumplimiento del artículo 12 de los estatutos sociales. El Juzgado de lo Mercantil núm. 7 de Madrid dicta sentencia el día 20 de mayo de 2010, en la que estima la impugnación y declara la nulidad de los acuerdos sociales adoptados en aquellas juntas generales. Ahora bien, la Audiencia Provincial de Madrid estima el recurso interpuesto, al considerar que «...(l)a actuación de aquél que, habiéndose antes comprometido, como todos los demás socios, a plegarse a unas nuevas reglas de funcionamiento de una sociedad, emprende luego, lo que entraña una paradoja, una acción de impugnación de acuerdos sociales mediante la que denuncia, exclusivamente, la aplicación de aquellas novedades convenidas para la adopción de decisiones en el seno de la junta general, por ser diferentes a las estatutarias, entraña el ejercicio de un derecho de forma contraria a las exigencias de la buena fe, lo que contraviene la previsión del $\mathrm{n}^{\mathrm{o}} 1 \mathrm{del}$ artículo $7 \mathrm{del} \mathrm{C}$. Civil y su proyección procesal contemplada en los artículos 11 de la LOPJ y 247 de la LEC; es más, podría incluso llegar a ser considerado su comportamiento como un intento de abuso de derecho, figura ésta proscrita por el $\mathrm{n}^{\mathrm{o}} 2$ del artículo 7 del C. Civil». Como resultado, la Audiencia concluye que «...el ulterior comportamiento de la parte actora emprendiendo las acciones de impugnación de los acuerdos sociales, pretendiendo que el tribunal atienda sólo a la formal infracción estatutaria y no examine el resto de los ingredientes que aderezan su actuación, resulta injustificable desde el punto de vista de la obligación que a todos incumbe de ejercitar los derechos de buena fe y de no incurrir en un abuso de derecho. Se trata de un motivo más que suficiente para que la demanda debiera haber sido rechazada y por eso estimamos ahora el recurso planteado por la entidad demandada contra la sentencia que no lo apreció así». De hecho, la RDGRN de 26 de octubre de 1989 -asunto «Promociones Keops»-- adoptó idéntica solución, es decir, reconocer eficacia societaria a un pacto parasocial, con base en el mismo argumento -la actuación contraria a la buena fe y el abuso de derecho-. En este caso, se cuestiona la actuación del registrador mercantil, que deniega la inscripción de los acuerdos adoptados en junta general de la mercantil «Promociones Keops, S.A.», al alegar mala fe del acreedor pignoraticio titular de todos los derechos de voto. En efecto, para poder conseguir financiación bancaria, el accionista único de la sociedad había celebrado un contrato de prenda sobre todas las acciones, en el que se pactó que los derechos políticos de estas últimas correspondían al deudor 
pignoraticio. El socio único aprovecha la doble circunstancia de que en los estatutos sociales se atribuía el derecho de voto al acreedor pignoraticio y de que el contrato de prenda era un contrato privado, inoponible a la sociedad, y celebra la junta. Sin embargo, el registrador rechaza la inscripción de los acuerdos adoptados en ella; decisión esta última confirmada posteriormente por la DGRN ${ }^{66}$.

Obsérvese que, en la sentencia de la Audiencia Provincial de Madrid de 16 de noviembre de 2012, la pretensión que se ejercita ante los tribunales no es impugnar un acuerdo social adoptado en contravención de un pacto parasocial. Antes bien, en al menos dos juntas generales el pacto parasocial origen remoto del conflicto ha sido respetado por los dos socios de la mercantil. No estamos, por tanto, ante un incumplimiento del pacto parasocial y la pretensión del otro socio -igualmente vinculado por el pacto- de anular un acuerdo social contrario a lo pactado por vía parasocial. De hecho, ambos socios respetan inicialmente el pacto, aunque uno de ellos procede posteriormente a impugnar los acuerdos adoptados, alegando para ello el incumplimiento de una norma estatutaria. En buena lógica, actúa de mala fe quien, habiéndose comprometido en un pacto parasocial en un determinado sentido, respeta dicho pacto en dos juntas generales, pero procede posteriormente a impugnarlas alegando el incumplimiento de una norma estatutaria. Ahora bien, como se señala en la sentencia, la Audiencia Provincial examina «circunstancias adicionales de suma relevancia» -0 , como también las denomina «el resto de los ingredientes que aderezan la situación»-, es decir, la existencia de un pacto parasocial en el que han intervenido los dos socios de la sociedad, el cual ha sido respetado por ambos socios en las dos juntas generales celebradas y la actuación posterior de uno de ellos, que procede a la impugnación de acuerdos adoptados en ellas. Esta toma en consideración de otros elementos concurrentes en el conflicto planteado determina que la Audiencia adopte la decisión de rechazar la

${ }^{66}$ La DGRN sostiene que «(C)omo son principios básicos de nuestro Ordenamiento jurídico que los derechos deberán ejercitarse conforme a las exigencias de la buena fe y que no debe protegerse el ejercicio abusivo de los derechos (art. 7), y como, además, es la necesaria protección de los derechos de los terceros que confían en la exactitud de las apariencias legítimamente creadas, la que determina el mantenimiento de la eficacia jurídica de aquellas actuaciones que, amparadas en los Estatutos sociales, contradicen la relación jurídica subyacente, no debe reconocerse la validez de aquella actuación en la que no se compromete todavía ningún derecho de terceros cuya protección reclamase su mantenimiento, pues no sólo es abusiva sino que además envuelve un incumplimiento contractual flagrante con grave detrimento para los propietarios de las acciones gravadas, que ven inutilizadas unas facultades jurídicas que legítimamente les pertenecen, aun cuando para su actuación precisen el debido concurso y colaboración del acreedor pignoraticio». 
impugnación ante ella planteada ${ }^{67}$, lo que en la práctica conlleva la eficacia del pacto parasocial frente a la sociedad.

\subsection{La eficacia societaria de los pactos parasociales de todos los socios o pactos parasociales omnilaterales}

Las decisiones jurisprudenciales ya citadas han planteado la necesidad de revisar la tradicional eficacia obligacional de los pactos parasociales, al menos para el caso en el que todos los socios de la sociedad han tomado parte en ellos. Se trata, por lo tanto, de una revisión de la eficacia de los pactos parasociales de todos los socios o pactos parasociales omnilaterales. Evidentemente, la exigencia de que en los pactos hayan intervenido todos los socios determina su celebración en el marco de sociedades con un número reducido de socios, unidos en ocasiones por vínculos familiares. Así, en el pacto parasocial objeto del asunto «Hotel Atlantis Playa»-STS 24 de septiembre de 1987- intervienen únicamente dos accionistas; las sentencias del asunto «Munaka»-SSTS de 26 de febrero de 1991 y de 10 de febrero de 1992- analizan un pacto parasocial en el que han tomado parte los cuatro accionistas, familia entre sí; en el pacto parasocial celebrado en el marco del grupo «Kurt Konrad y Cía, S.A.» intervienen los dos grupos familiares propietarios de las acciones y participaciones de las sociedades que forman parte del grupo -STS de 10 de diciembre de 2008, STS de 5 de marzo de 2009 y SSTS de 6 de marzo de 2009-; y, por último, la reciente sentencia de la Audiencia Provincial de Madrid de fecha 16 de noviembre de 2012 -asunto «Prevención Outsourcing, S.L.» se pronuncia sobre un pacto parasocial en el que participan los dos únicos socios de la sociedad. Por el contrario, esta revisión de la eficacia de los pactos parasociales no puede trasladarse a aquellos pactos en los que únicamente intervienen algunos socios, al existir co-socios ajenos al pacto.

Durante décadas, los pactos parasociales estuvieron rodeados de un halo de ilicitud, por tratarse de pactos no incluidos en los estatutos sociales y que, por tanto, tampoco constaban en el Registro Mercantil. De hecho, no ha sido hasta bien avanzado el siglo XX cuando la jurisprudencia española ha declarado la validez y licitud de los pactos parasociales y, hasta comienzos de este siglo, cuando el legislador español ha reconocido expresamente su existencia al regular precisamente la publicidad de los pactos parasociales en el marco

${ }^{67}$ «Consideramos que ante esas circunstancias el ulterior comportamiento de la parte actora emprendiendo las acciones de impugnación de los acuerdos sociales, pretendiendo que el tribunal atienda sólo a la formal infracción estatutaria y no examine el resto de los ingredientes que aderezan su actuación, resulta injustificable desde el punto de vista de la obligación que a todos incumbe de ejercitar los derechos de buena fe y de no incurrir en un abuso de derecho. Se trata de un motivo más que suficiente para que la demanda debiera haber sido rechazada y por eso estimamos ahora el recurso planteado por la entidad demandada contra la sentencia que no lo apreció así». 
de las sociedades cotizadas -véanse art. 112 LMV y los actualmente en vigor arts. 530 y ss. LSC-. Pues bien, el mencionado carácter secreto u oculto de los pactos parasociales fácilmente conducía a sostener que aquellos tenían por objeto un contenido pretendidamente prohibido. Siguiendo esta lógica, si los socios ocultaban el pacto por ellos celebrado era porque contenía acuerdos que no podían salir a la luz. Nada más lejos de la realidad. En este sentido, como ya hemos señalado, la categoría de los contratos parasociales comprende aquellos acuerdos en los que intervienen todos o algunos de los socios de una sociedad, mediante los cuales aquéllos completan o modifican el régimen legal o estatutario previsto para la sociedad, comprometiéndose a actuar de un modo predeterminado. No cabe, por tanto, una identificación absoluta entre pacto parasocial y contenido prohibido. Es más, el carácter secreto o confidencial constituye una de las ventajas que presentan los pactos parasociales, junto con su sencillez, flexibilidad y su capacidad de adaptación. Cuestión distinta, evidentemente, es que, en determinadas ocasiones, un concreto pacto parasocial sea ilícito ${ }^{68}$.

La circunstancia de la falta de acceso de los pactos parasociales al Registro Mercantil implica, evidentemente, la imposibilidad de conocimiento de lo pactado por parte de quienes no han intervenido en el pacto en cuestión, es decir, socios no participantes en el mismo y terceros. Ahora bien, en el supuesto particular de pactos parasociales omnilaterales, su contenido es conocido por todos los socios, en la medida en que todos ellos han tomado parte en su celebración. Sin embargo, la no incorporación de los pactos parasociales a los estatutos no tiene por qué ser enjuiciada como una actuación negligente o ligera de los socios ${ }^{69}$. Al contrario, se suele tratar de una decisión consciente, movida normalmente por el deseo de los socios de sustraer dichos pactos de la publicidad registral. En efecto, con base en la declaración contenida en el artículo 29 LSC, la inoponibilidad de un concreto pacto a la sociedad pasa necesariamente por que este último sea reservado, es decir, no conste en los estatutos sociales; opción que conlleva que su contenido no pueda ser conocido por terceros ajenos a la sociedad. A su vez, este pretendido o buscado desconocimiento por parte de terceros de la existencia y del contenido del pacto puede responder a distintos motivos. Así, en ocasiones, esta decisión puede deberse al deseo de querer mantener oculto el pacto para que su contenido no sea conocido por terceros; conocimiento que, a su vez, podría ser perjudicial para la sociedad, para algunos socios o para un terce-

${ }^{68}$ Sobre la licitud de los pactos parasociales resulta imprescindible la lectura de PAzAres, C., «La cuestión de la validez de los pactos parasociales», Actualidad jurídica Uría Menéndez, núm. extraordinario, Homenaje al profesor D. Juan Luis Iglesias Prada, 2011, p. 252 y ss., e, igualmente, con alguna modificación, en Diario La Ley, núm. 7714.

${ }^{69}$ Véase Noval Pato, J., Los pactos omnilaterales: su oponibilidad a la sociedad. Diferencias y similitudes con los estatutos y los pactos parasociales, ob. cit., p. 92. 
ro $^{70}$. Pero también mediante un pacto parasocial los socios pueden pactar cuestiones relacionadas con el funcionamiento de la sociedad, cuya previsión en los estatutos sociales exigiría proceder a una modificación de los mismos, con el coste económico y temporal que conlleva ${ }^{71}$. En este caso, la flexibilidad, la sencillez y la capacidad de adaptación inherentes al pacto parasocial, apuntadas anteriormente, justificarían esta opción. Igualmente, los socios pueden preferir celebrar un pacto parasocial para, de este modo, garantizarse que el contenido del pacto únicamente podrá ser objeto de modificación por unanimidad y no por la mayoría exigible legalmente en caso de que tales acuerdos estuvieran previstos en los estatutos sociales ${ }^{72}$. En definitiva, resulta simplista identificar desconocimiento por parte de terceros con intención aviesa por parte de los socios intervinientes en el pacto. Habrá ocasiones en que efectivamente así sea, pero otras en las que aquellos busquen otros fines, como los ya señalados.

Resta, en cualquier caso, afrontar la cuestión relativa a la relación existente entre pacto parasocial y sociedad. Como hemos señalado en varias ocasiones a lo largo del presente trabajo, tradicionalmente se ha sostenido que los pactos parasociales presentan una eficacia «inter partes», es decir, exclusivamente entre los participantes en ellos, pero no «erga omnes», de modo que la sociedad y los terceros quedan al margen de aquellos ${ }^{73}$. Y precisamente esta característica de los pactos parasociales impide el recurso a mecanismos o instrumentos del Derecho de sociedades para reclamar o forzar el cumplimiento o, en su caso, para sancionar el incumplimiento de lo convenido en tales pactos parasociales. Se trataría de una manifestación del principio de relatividad de los contratos, atendiendo al cual los contratos únicamente producen efecto entre las partes que los otorgan, pero no pueden afectar a terceros ajenos -art. 1257 Cciv-. En particular, esta separación absoluta entre pactos parasociales y sociedad se ha fundamentado en argumentos tales como la plena autonomía e independencia de la sociedad frente a los socios o la obligada utilización de los órganos sociales -y el consiguiente cumplimiento de las exigencias legales y, en su caso, estatutarias- para configurar la voluntad

70 Así, Noval Pato, J., Los pactos omnilaterales: su oponibilidad a la sociedad. Diferencias y similitudes con los estatutos y los pactos parasociales, ob. cit., pp. 93 y 94, pone como ejemplo el interés para los socios de privar a la competencia el acceso a acuerdos en los que se detalla o incide sobre la estrategia empresarial de la sociedad.

71 Por su parte, SÁez Lacave, Ma . I., «Los pactos parasociales de todos los socios en Derecho español. Una materia en manos de los jueces», ob. cit., p. 8, sostiene que «(L)a razón por la cual las partes no tienen interés en dotar a estos pactos de rango estatutario es simplemente porque no les aporta ningún beneficio adicional y, en cambio, les resta eficacia».

72 Tal y como apunta Sáez Lacave, Ma . I., «Los pactos parasociales de todos los socios en Derecho español. Una materia en manos de los jueces», ob. cit., p. 8.

${ }^{73}$ No nos referimos a socios ajenos al pacto puesto que estamos refiriéndonos a pactos omnilaterales, en los que, por lo tanto, han participado todos los socios de la sociedad. 
de la sociedad e integrar su ordenamiento ${ }^{74}$. Sin embargo, estos argumentos han sido objeto de matización. Así, la pretendida plena autonomía de la sociedad frente a los socios no explica que estos últimos, aun siendo terceros, puedan incidir en el ordenamiento societario a través de su participación en los órganos sociales ${ }^{75}$. A su vez, aun cuando es cierta la afirmación de que es mediante el recurso a los órganos sociales como los socios configuran la voluntad de la sociedad, ello no implica que necesariamente esta sea la única vía de regular y organizar la vida social ${ }^{76}$. De hecho, los pactos parasociales omnilaterales pueden constituir un mecanismo óptimo para ello, dadas las ventajas inherentes a los mismos. Como resultado, la inoponibilidad tiene razón de ser en los supuestos de pactos parasociales en los que intervienen exclusivamente algunos socios, pero no en los casos de pactos parasociales de todos los socios, los cuales vinculan a estos últimos y a la sociedad, aunque no a terceros ajenos a tales pactos ${ }^{77}$.

\subsection{Consecuencias de la eficacia societaria de los pactos parasociales de todos los socios o pactos parasociales omnilaterales}

La admisión de eficacia societaria de los pactos parasociales de todos los socios conduce necesariamente a plantear la posibilidad de que los socios se sirvan de los instrumentos existentes en el Derecho de sociedades para hacerlos valer. Sin duda, dentro de tales instrumentos, destaca el recurso al procedimiento de impugnación de acuerdos sociales, ya que habitualmente el conflicto se suscita como consecuencia de la adopción de un acuerdo social por parte de la junta general en contravención de lo acordado en un pacto parasocial. Ahora bien, la rotundidad con la que se ha pronunciado el Tribunal Supremo en las últimas sentencias dictadas sobre la materia-SSTS

${ }^{74}$ Así, Noval Pato, J., Los pactos omnilaterales: su oponibilidad a la sociedad. Diferencias y similitudes con los estatutos y los pactos parasociales, ob. cit., pp. 83 y 84, con ulteriores referencias bibliográficas.

${ }^{75}$ Véase Noval Pato, J., Los pactos omnilaterales: su oponibilidad a la sociedad. Diferencias y similitudes con los estatutos y los pactos parasociales, ob. cit., pp. 83 y 84.

${ }^{76}$ En efecto, como apuntan SÁez Lacave, Ma ${ }^{a}$ I., «Los pactos parasociales de todos los socios en Derecho español. Una materia en manos de los jueces», ob. cit., p. 4, «... los acuerdos de todos los accionistas son en sustancia complemento del contrato social tal y como se recoge en los estatutos, de tal manera que juntos - pactos más estatutosconforman desde una óptica económica, un contrato -más - completo de sociedad»; o Noval Pato, J., Los pactos omnilaterales: su oponibilidad a la sociedad. Diferencias y similitudes con los estatutos y los pactos parasociales, ob. cit., p. 87, «...se hace difícil de entrever los motivos por los que no resulta conveniente que los socios no puedan obligar en ningún caso a la sociedad sin contar con la junta general y sin dejar constancia en los estatutos de lo convenido»».

77 En este sentido, Vicent Chuliá, F., Introducción al Derecho mercantil, $23^{\mathrm{a}}$ ed., Volumen I, Tirant lo Blanch, Valencia, 2012, p. 569; o Noval Pato, J., Los pactos omnilaterales: su oponibilidad a la sociedad. Diferencias y similitudes con los estatutos y los pactos parasociales, ob. cit., p. 137. 
de 10 de diciembre de 2008, de 5 de marzo de 2009 y de 6 de marzo de 2009- obligan a reconducir la impugnación de un acuerdo societario adoptado en incumplimiento de un pacto parasocial a los cauces del artículo 204 LSC -antiguo art. 115 LSA 1989-. En efecto, las afirmaciones realizadas por el Tribunal Supremo en las mencionadas sentencias no sólo confirman la posibilidad de servirse de alguna de las vías de impugnación ex artículo 204 LSC. De hecho, fuerzan a ello. Como resultado, la mera alegación de la infracción de un pacto parasocial a efectos de la impugnación de un acuerdo social no resultará suficiente. Tampoco lo será invocar razones de economía procesal, sosteniendo que se puede obtener el mismo resultado mediante la utilización de instrumentos del Derecho de obligaciones y contratos, si bien con unos costes mayores ${ }^{78}$. Será necesario servirse de alguno de los cauces impugnatorios previstos legalmente ${ }^{79}$. Esta propuesta ya fue planteada hace algunos años por el profesor Paz-Ares, el cual sostuvo incluso una integración analógica de los motivos de impugnación previstos legalmente ${ }^{80}$, aunque también reconoció que no había obstáculos para alcanzar el mismo resultado mediante la inserción en alguno de los cauces típicos previstos en el ordenamiento ${ }^{81}$.

78 Tal y como se sostuvo en la sentencia del BGH de 20 de enero de 1983, mencionada en páginas anteriores. En nuestra doctrina, PAZ-ARES, C., «El "enforcement" de los pactos parasociales», ob. cit., p. 37, se sirve de este argumento para concluir que «...carece de sentido - de cualquier tipo de racionalidad juridica-impedir que se invoque directamente la infracción del pacto parasocial para impugnar los acuerdos sociales. Lo contrario obligaría a un calvario inútil: a dejar vigente provisionalmente el acuerdo; a ejecutar in natura el pacto parasocial y, sobre la base de la acción de remoción (artículo 1098.II CC in fine), a promover una junta para dejar sin efecto el acuerdo social». Por su parte, en el asunto objeto de la sentencia de la Audiencia Provincial de Madrid de 16 de noviembre de 2012, la parte demandada igualmente se sirve del argumento de la economía procesal en defensa de la eficacia societaria del pacto parasocial («...porque podría exigirse el cumplimento de la obligación contractual para llegar al mismo resultado práctico que si se mantuviesen los acuerdos adoptados»), así como del argumento de la inadmisbilidad de la conducta contradictoria de la demandante.

79 Por el contrario, Feliú Rey, J., Los pactos parasociales en las sociedades de capital no cotizadas ob. cit., p. 361 y ss., se manifiesta crítico con la posibilidad de impugnar un acuerdo social por violación de un pacto parasocial, concluyendo que «...actualmente, y conforme a la regulación vigente, resulta difícil sostener la oponibilidad del pacto a la sociedad, y todas las soluciones doctrinales y jurisprudenciales que están permitiendo hacerlo no dejan de ser "parches" que lo único que revelan, en realidad, es la necesidad urgente de dotar de una regulación concreta y clara a la figura de los pactos parasociales, lo mismo que ocurrió con la cuestión de la validez de los mismos».

${ }^{80}$ Véase Paz-Ares, C., «El “enforcement” de los pactos parasociales», ob. cit., p. 39. En contra de esta propuesta, Pérez Millán, D., «Presupuestos y fundamento jurídico de la impugnación de acuerdos sociales por incumplimiento de pactos parasociales», ob. cit., p. 252, que señala que no debiera concluirse la existencia de un nuevo motivo de impugnación, si es posible encontrar apoyo en alguno de los motivos tipificados legalmente.

${ }^{81}$ Así, PAZ-Ares, C., «El "enforcement” de los pactos parasociales», ob. cit., p. 40. 
Por lo demás, el recurso al primer cauce impugnatorio, es decir, la contravención de la ley, requeriría justificar que la actuación contraria a lo pactado en un pacto parasocial constituye una vulneración de alguna disposición legal. Así, cierto sector doctrinal ha apuntado que los acuerdos sociales adoptados en violación de pactos parasociales firmados por todos los socios son nulos por contrarios a la ley, por constituir abuso de derecho - por lo tanto,

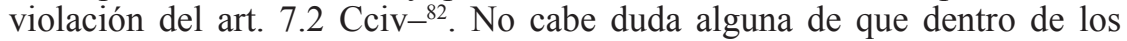
acuerdos nulos quedan incluidos los acuerdos que conllevan una violación de cláusulas generales del ordenamiento jurídico, como es el caso de los acuerdos adoptados con abuso del derecho; si bien el problema fundamental que se suscita no es otro que la prueba de la existencia del abuso alegado ${ }^{83}$. A esta observación se ha de sumar otra de mayor entidad como es que esta solución es artificiosa, tanto en los medios como en los resultados que alcanza, y difícilmente aceptable, puesto que conllevaría que la violación de un pacto parasocial recibe un mejor tratamiento en materia de caducidad y legitimación que la violación de los estatutos sociales ${ }^{84}$. En efecto, ha de recordarse que para la impugnación de los acuerdos nulos, la LSC reconoce legitimación a todos los socios, a los administradores y a cualquier tercero que acredite un interés legítimo, mientras que para la impugnación de acuerdos anulables, están legitimados los socios asistentes a la junta que hayan hecho constar en acta su oposición al acuerdo, los ausentes, los que hubiesen sido ilegítimamente privados de su derecho de voto y los administradores -art. 206 LSC-. Del mismo modo, si la acción de nulidad caduca en el plazo de un año, con la única excepción de los acuerdos que, por su causa o contenido, sean contrarios al orden público, los cuales no caducan, la acción de anulabilidad caduca a los cuarenta días -art. 205 LSC-.

A su vez, la eventual alegación del segundo motivo de impugnación ex artículo 204 LSC -es decir, contravención de los estatutos sociales- pasaría por equiparar pacto parasocial con cláusula estatutaria. A tal efecto, se ha sostenido que los pactos parasociales constituyen reglas interpretativas de los estatutos, de modo que el incumplimiento de los primeros conllevaría un incumplimiento de los estatutos sociales. Sin embargo, esta opción únicamente sería admisible en aquellos casos en que, efectivamente, el pacto parasocial infringido sirviera de elemento interpretativo de una cláusula estatutaria, ya que los pactos parasociales no son siempre un mecanismo de interpretación

${ }^{82}$ En este sentido, Vicent Chuliá, F., Introducción al Derecho mercantil, ob. cit., pp. 569 y 732

${ }_{83}$ Por todos, Rojo, A, en Rojo, A. y Beltrán, E. (coords.), Comentario de la Ley de Sociedades de Capital, ob. cit., p. 1440.

${ }^{84}$ Como señala PAZ-Ares, C., «El "enforcement" de los pactos parasociales», ob. cit., p. 40. Por su parte LaCAVE, $\mathrm{M}^{\mathrm{a}}$. I., "Los pactos parasociales de todos los socios en Derecho español. Una materia en manos de los jueces», ob. cit., p. 21, califica esta vía como «desproporcionada». 
de los estatutos ${ }^{85}$. Por su parte, las similitudes existentes entre pactos parasociales omnilaterales y estatutos podrían conducir, en principio, a acoger un concepto amplio de estos últimos en tanto solución legitimadora de la impugnación. Sin embargo, en sentido estricto, para que se trate de un acuerdo anulable por contrariedad a los estatutos sociales, se requiere que el acuerdo cuestionado vulnere una norma introducida en los estatutos originarios o modificados dentro de los márgenes de la autonomía privada ${ }^{86}$. Evidentemente, este no es el caso del acuerdo social adoptado en contravención de un pacto parasocial $^{87}$.

El rechazo a los anteriores cauces impugnatorios obliga a recurrir al último de los previstos en el artículo 204 LSC, es decir, la lesión de los intereses de la sociedad. Ha de tenerse presente que este es precisamente el argumento del que se sirvió el Tribunal Supremo en la sentencia de 10 de febrero de $1992^{88}$-asunto «Munaka»- En efecto, la adopción de un acuerdo social adoptado en contravención de un pacto parasocial en el que han intervenido todos los socios conlleva una desconsideración de sus intereses y, por tanto, una lesión del interés social ${ }^{89}$. Idéntica conclusión ha de adoptarse en caso de considerar que los pactos parasociales omnilaterales conforman el ordenamiento jurídico de la sociedad, junto con la ley y los estatutos, es decir, que aquellos presentan eficacia organizativa, de modo que contribuyen a gober-

${ }^{85}$ Ver Paz-Ares, C., «El "enforcement” de los pactos parasociales», ob. cit., p. 40, que también reconoce que esto no quiere decir que en ocasiones no quepa traer a colación pactos parasociales para fundamentar una impugnación por infracción de los estatutos, por ejemplo, cuando existe una cláusula estatutaria que puede ser interpretada o concretada con ayuda de los pactos parasociales.

${ }^{86}$ Al respecto, Rojo, A, en Rojo, A. y Beltrán, E. (coords.), Comentario de la Ley de Sociedades de Capital, ob. cit., p. 1441.

87 También Noval Pato, J., Los pactos omnilaterales: su oponibilidad a la sociedad. Diferencias y similitudes con los estatutos y los pactos parasociales, ob. cit., p. 138, reconoce que esta propuesta no se corresponde con una interpretación literal del art. 204 LSC.

${ }^{88}$ Así, en esa ocasión, el mencionado tribunal concluye que «...la lesión de los intereses de la sociedad, en beneficio de uno o varios accionistas (que es una de las causas de impugnación contempladas en el precepto invocado) puede producirse mediante acuerdos sociales adoptados con la intervención de las circunstancias tipificadoras del abuso de derecho (subjetiva, de intención de perjudicar o falta de una finalidad seria, y objetiva, de anormalidad en el ejercicio del mismo), que es lo ocurrido en el presente supuesto litigioso...».

${ }^{89}$ Así, Vicent Chuliá, F., Introducción al Derecho mercantil, ob. cit., p. 731; PazAres, C., «El "enforcement" de los pactos parasociales», ob. cit., p. 41; SÁez Lacave, $M^{a}$. I., «Los pactos parasociales de todos los socios en Derecho español. Una materia en manos de los jueces», ob. cit., pp. 21 y 22, que señala que el mayor escollo para que esta argumentación prospere en vía judicial es el escaso desarrollo jurisprudencial del contenido de los deberes fiduciarios de los socios, que es lo que está detrás de la protección del interés social del art. 115 LSA 1989, y que obliga a buscar otros motivos de impugnación con mayores probabilidades de éxito; o Pérez Millán, D., «Presupuestos y fundamento jurídico de la impugnación de acuerdos sociales por incumplimiento de pactos parasociales», ob. cit., p. 254 y ss. 
nar la vida de la sociedad ${ }^{90}$. Desde esta consideración, el incumplimiento de un pacto parasocial en el que han participado todos los socios constituye una infracción del deber de fidelidad del socio y, en último término, del interés social $^{91}$. Recuérdese que la ley española acoge una concepción contractualista del interés social, de modo que identifica el interés de la sociedad con el interés común de los socios; concepción que también ha sido sostenida por el Tribunal Supremo ${ }^{92}$. En buena lógica, para la procedencia de la impugnación del acuerdo social por ser lesivo a los intereses de la sociedad, se requerirá la concurrencia de los requisitos que determinan, en general, la existencia de una situación de conflicto de intereses entre la sociedad y uno de sus socios; requisitos que no sólo han de ser alegados, sino probados de forma suficien$t^{93}$. Con todo, en estos supuestos, el contenido de los deberes de fidelidad ha sido previamente concretado convencionalmente, ya que la conducta debida por el socio se ha especificado en el pacto parasocial infringido en el que aquel ha tomado parte ${ }^{94}$.

Por otra parte, el problema relativo a la posible eficacia societaria de los pactos parasociales omnilaterales también se ha planteado desde otra vertiente: la adopción de acuerdos sociales en junta respetando lo convenido en un pacto parasocial y el posterior inicio de un procedimiento de impugnación de acuerdos sociales con base en la alegación de que el acuerdo o acuerdos adoptados contravienen lo previsto en los estatutos sociales. Se trata de los hechos objeto de la sentencia de la Audiencia Provincial de Madrid de 16

90 Tal y como sostiene Noval Pato, J., Los pactos omnilaterales: su oponibilidad a la sociedad. Diferencias y similitudes con los estatutos y los pactos parasociales, ob. cit., p. 98.

91 Ver Noval Pato, J., Los pactos omnilaterales: su oponibilidad a la sociedad. Diferencias y similitudes con los estatutos y los pactos parasociales, ob. cit., p. 98 y 138.

92 Así, ver, entre otras, SSTS de 19 de febrero de 1991 (Ar. 1991/1512); de 24 de septiembre de 1998 (Ar. 1998/7068); de 4 de marzo de 2000 (Ar. 2000/1502); de 12 de julio de 2002 (Ar. 2002/8252); de 5 de marzo de 2004 (Ar. 2004/1807); de 11 de noviembre de 2005 (Ar. 2005/7769); o de 17 de marzo de 2006 (Ar. 2006/1886). Con todo, tal y como reconoce SÁez LACAVE, $M^{a}$. I., «Los pactos parasociales de todos los socios en Derecho español. Una materia en manos de los jueces», ob. cit., p. 21, el TS es reacio a admitir la impugnación de acuerdos neutrales respecto de la sociedad, aunque perjudiquen a unos socios en beneficio de otros; si bien en los casos más extremos de deslealtad del socio mayoritario en el ejercicio del derecho de voto, también ha reaccionado defendiendo a los socios minoritarios mediante el recurso a argumentos que recuerdan estrategias utilizadas en el marco de los pactos parasociales.

93 Por todos, Rojo, A, en Rojo, A. y Beltrán, E. (coords.), Comentario de la Ley de Sociedades de Capital, ob. cit., p. 1444, con base en constante jurisprudencia.

${ }^{94}$ Tal y como apuntan SÁEz Lacave, Ma . I., «Los pactos parasociales de todos los socios en Derecho español. Una materia en manos de los jueces», ob. cit., p. 22; o Pérez Millán, D., «Presupuestos y fundamento jurídico de la impugnación de acuerdos sociales por incumplimiento de pactos parasociales», ob. cit., p. 255. 
de noviembre de $2012^{95}$, que resuelve el conflicto planteado en relación con un pacto parasocial en el que también han participado todos los socios de la sociedad $^{96}$, es decir, un pacto parasocial omnilateral. Pues bien, esta situación pone igualmente de manifiesto la problemática que subyace en buena parte de los conflictos que se suscitan en materia de pactos parasociales. Tal y como ya fue apuntado en su día ${ }^{97}$, el juez se encuentra ante el dilema de observar estrictamente la letra de la ley y, con ello, permitir que el ordenamiento acabe amparando a quien actúa de forma antijurídica o, por el contrario, no permitir dicha actuación, lo que implica, en definitiva, el cumplimiento del pacto y, en último término, el reconocimiento de su eficacia societaria. De hecho, la propia Audiencia Provincial de Madrid parte de la premisa de que «...no bastaba para resolver el caso con la simple invocación de la jurisprudencia que antes hemos citado, que resuelve casos que no presentan identidad de razón con el que nos ocupa, como tampoco sería suficiente la mera constatación de la comisión de una formal infracción estatutaria, que, contemplada de forma aislada, parecería innegable, cuando hay circunstancias adicionales de suma relevancia y cuya toma en consideración deberían deparar una suerte al resultado del litigio distinta de la que le ha deparado la primera instancia de este proceso»». La observancia estricta de la ley conduciría inexorablemente a admitir la infracción estatutaria y, por consiguiente, a declarar la nulidad de los acuerdos adoptados. Sin embargo, la actuación de quien se compromete en un pacto parasocial a actuar en un determinado sentido, así lo respeta en una o varias ocasiones, pero posteriormente procede a impugnar los acuerdos sociales adoptados infringe el principio de la buena fe, declarado en el artículo 7.1 Cciv. En efecto, el ejercicio de un derecho subjetivo es contrario a la buena fe siempre que se ejercita de una forma o en unas circunstancias que lo hacen desleal ${ }^{98}$. $\mathrm{Y}$ de este principio general deriva la inadmisibilidad de la actuación contra los actos propios o «venire contra factum propium», que impone un deber de proceder lealmente en las

95 Así, en esta sentencia se aclara que «(S)e trata de una manera distinta de plantear el problema, porque el pacto parasocial se habría cumplido en sus precisos términos y nos hallaríamos, por lo tanto, ante una situación tan peculiar como lo es la del socio que previamente se había obligado a cumplir aquél y que, sin embargo, luego decide desentenderse de ello, pretendiendo combatir sus efectos al reclamar la aplicación de las reglas societarias que todavía permanecen incorporadas a los estatutos sociales, aunque no se aviniesen con aquél, porque aun no habían sido formalmente cambiadas».

${ }^{96}$ De hecho, a esta circunstancia se refiere expresamente la sentencia al señalar que «(C)onsideramos que la actuación de aquél que, habiéndose antes comprometido, como todos los demás socios, a plegarse a unas nuevas reglas de funcionamiento de una sociedad....».

${ }^{97}$ Así, Sáez Lacave, Mª . I., «Los pactos parasociales de todos los socios en Derecho español. Una materia en manos de los jueces», ob. cit., pp. 3 y 17.

98 Por todos, Miquel GonzÁlez, J. Ma , «Comentario al artículo 7.1 del Código civil», en AA.VV., Comentario del Código civil, Tomo I, Secretaría General Técnica, Centro de Publicaciones, Madrid, 1991, p. 37 y ss. 
relaciones de derecho y, en particular, la exigencia de una coherencia en la conducta que despierta expectativas en los demás. Se trata, obsérvese, de un supuesto en el que el socio impugnante ha participado en la celebración de un pacto parasocial, que, posteriormente, ha sido respetado en la adopción de acuerdos sociales en junta. Por tanto, cabe exigirle un comportamiento consecuente con la confianza que previamente ha creado, dado el respeto al contenido del pacto parasocial ${ }^{99}$, y que quiebra como consecuencia del inicio del procedimiento de impugnación de acuerdos sociales. Así, aquel socio ha observado una conducta jurídicamente relevante, como es su participación en la adopción de acuerdos sociales en junta, respetando el contenido del pacto parasocial. Posteriormente, el mismo socio - es decir, existe identidad de sujetos entre conducta anterior y pretensión posterior- inicia un procedimiento de impugnación de acuerdos sociales-, de modo que crea una situación litigiosa, formulando dentro de ella la pretensión de anular los acuerdos sociales adoptados en junta. Además, entre la actuación inicial de cumplimiento del contenido del pacto parasocial y la posterior actuación de impugnación de los acuerdos sociales adoptados existe una evidente contradicción. En buena lógica, el ordenamiento no puede amparar actuaciones incompatibles o contradictorias con la conducta anterior de respeto al pacto parasocial, lo que debe conducir a la desestimación de la demanda de impugnación de acuerdos sociales. A su vez, esta desestimación conlleva el reconocimiento de eficacia societaria del pacto parasocial.

En definitiva, la tradicional eficacia «inter partes» de los pactos parasociales, que implica que únicamente son eficaces entre los socios participantes en los mismos, ha de ser revisada. Este replanteamiento ya fue tímidamente iniciado por nuestros tribunales en algunas sentencias dictadas hace algunos años, si bien con base en argumentos poco sólidos. De ahí la necesidad de servirse de razonamientos de mayor entidad para salvar definitivamente el punto débil de los pactos parasociales, que no es otro que su limitada eficacia. En este sentido, aquellos pactos parasociales que vinculan únicamente

99 Es más, la sentencia de la Audiencia Provincial de Madrid de 12 de noviembre de 2012, fundamenta la actuación contraria a la buena fe del demandante no sólo en la falta de respeto a lo previamente comprometido, sino también en la ausencia de impugnación en plazo de la primera de las juntas objeto del litigio, ya que «si se consideraba que ya se había cometido entonces una infracción de los estatutos sociales, al no ajustarse el presidente a éstos, sino al pacto parasocial, a la hora de computar el quorum de votos favorables para la aprobación de los acuerdos, debería haberse planteado la impugnación en el plazo de 40 días -artículo 56 de la LSRL en relación con el artículo 116 del TRLSA, preceptos entonces vigentes, coincidente con la previsión del artículo 205 del TR de la Ley de Sociedades de Capital 1/2010, que es la norma ahora en vigor-, sin que fuera admisible aducir luego, para obviar dicho lapso de caducidad, como se pretendió con la demanda iniciadora del presente litigio, una inexistente infracción legal, que no podría prosperar, pues tanto el quórum estatutario como el del convenio parasocial eran superiores al previsto en el artículo 53 de la LSRL -artículos 198 y 199 del vigente TR de la Ley de Sociedades de Capital 1/2010-». 
a parte de los socios de la sociedad no pueden tener eficacia ni frente a la sociedad, ni frente a los socios no participantes en ellos ni frente a terceros. Sin embargo, una solución distinta ha de darse a los pactos parasociales de todos los socios o pactos omnilaterales, que suelen celebrarse en el marco de sociedades con un número reducido de socios, generalmente conectados por vínculos familiares o personales. En efecto, estos pactos no son desconocidos por los socios, en la medida en que todos ellos han participado en su celebración. Además, la sociedad tampoco es un tercero ajeno a los mismos. Por ello, debe entenderse que esta concreta modalidad de pactos parasociales presenta eficacia no sólo «inter partes», es decir, entre los socios que los han celebrado -que, recuérdese, son todos los socios de la sociedad-, sino también frente a la sociedad. Tienen, por tanto, eficacia societaria, pero no «erga omnes». En buena lógica, la eficacia frente a la sociedad de los pactos parasociales se suele poner en cuestión en situaciones de conflicto. Habitualmente, esta situación conflictiva se produce como consecuencia de la adopción de acuerdos en junta en contravención de lo pactado en el pacto parasocial. Sin embargo, de forma excepcional, también se puede producir en el caso de adopción de acuerdos en junta en cumplimiento del pacto parasocial, pero posterior inicio de un procedimiento de impugnación de acuerdos sociales por contradicción con normas estatutarias. Pues bien, tanto en uno como en otro caso, el ordenamiento jurídico no puede proteger conductas que chocan con los compromisos asumidos libremente por los socios por su participación en el pacto parasocial y que, por tanto, deben ser respetados. En el primer supuesto, será necesario impugnar los acuerdos sociales adoptados con base en la lesión del interés social, mientras que en el segundo caso, deberá desestimarse la impugnación con base en la actuación contraria a los actos propios que dicho comportamiento conlleva. No podemos compartir, por tanto, la declaración contenida en la Propuesta de Código Mercantil, a tenor de la cual los acuerdos sociales adoptados en contra de lo previsto en los pactos serán válidos. A nuestro juicio, el régimen general de los pactos parasociales contenido en dicha Propuesta $-\mathrm{y}$, particularmente, la cuestión relativa a su eficacia- requiere una reflexión en esta nueva fase que inicia, al menos en relación con los pactos parasociales omnilaterales.

RESUMEN: La tradicional eficacia «inter partes» de los pactos parasociales, que implica que únicamente son eficaces entre los socios participantes en los mismos, ha de ser revisada. Este replanteamiento ya fue tímidamente iniciado por nuestros tribunales en algunas sentencias dictadas hace algunos años, si bien con base en argumentos poco sólidos. De ahí la necesidad de servirse de razonamientos de mayor peso para salvar definitivamente el punto débil de los pactos parasociales, que no es otro que su limitada eficacia. En este sentido, aquellos pactos parasociales que vinculan únicamente a parte de los socios de la sociedad no pueden tener eficacia ni frente a la sociedad, ni frente a los socios no participantes en ellos ni frente a terceros. Sin embargo, una solución distinta ha de darse 
a los pactos parasociales de todos los socios o pactos omnilaterales, que suelen celebrarse en el marco de sociedades con un número reducido de socios, generalmente conectados por vínculos familiares o personales. En efecto, estos pactos no son desconocidos por los socios, en la medida en que todos ellos han participado en su celebración. Además, la sociedad tampoco es un tercero ajeno a los mismos. Por ello, debe entenderse que esta concreta modalidad de pactos parasociales presenta eficacia no sólo «inter partes», sino también frente a la sociedad.

Palabras Clave: Sociedades, pactos parasociales, eficacia frente a la sociedad, revisión.

TITLE: The needed review of the effectiveness of parasocial omnilateral shareholder agreements.

ABSTRACT: The traditional efficiency «inter partes» of shareholders agreements -they will only be effective to the partners involved in them-, must be revised. This rethinking was timidly initiated by our courts in some judgments years ago, although based on unsound arguments. It is necessary to use heavier reasoning to save definitely the weak point of shareholders agreeements: its limited effectiveness. In this sense, those agreements that bind only some partners of corporation can not be executed or against society or against partners not participating in them or third parties. However, a different solution must be given to shareholders agreements that bind all partners, which usually take place in the context of companies with a small number of partners, usually connected by family or personal ties. These agreements are not unknown by the partners, because all of them have taken part in the meeting. In addition, the company is not a strange to them. Therefore, it should be understood that this particular form of shareholder agreements have efficacy not only "inter partes», but also against the society.

KEYWORDS: Corporations, shareholders agreements, efficacy against corporation, review.

Recibido: 15.07 .2013

Aceptado: 02.09.2013 